\title{
PROPOSTA PROJETUAL DE UM MUSEU DE ARTE NA CIDADE DE CUIABÁ - MT
}

\section{ARTIGO ORIGINAL}

MACHADO, Érika Pereira ${ }^{1}$

MACHADO, Carlos Antônio Moraes ${ }^{2}$

RASGA, Frederico Sucena ${ }^{3}$

MACHADO, Érika Pereira. MACHADO, Carlos Antônio Moraes. RASGA, Frederico Sucena. Proposta Projetual de um museu de arte na cidade de Cuiabá - MT. Revista Científica Multidisciplinar Núcleo do Conhecimento. Ano 05, Ed. 01, Vol. 06, pp. 147-181. Janeiro de 2020. ISSN: 2448-0959, Link de acesso: https://www.nucleodoconhecimento.com.br/arquitetura/proposta-projetual

\section{RESUMO}

Este trabalho tem por objetivo, sugerir a ocupação e transformação de espaços públicos, com projetos arquitetônicos que valorizem a vida social e cultural da população. Pretende-se criar o espaço "Museu de Arte" na capital Cuiabá, que seja referência para o estado oferecendo lazer, entretenimento e cultura. A área destinada à implantação do projeto está localizada no Bairro do Porto, região historicamente importante para a capital do Mato Grosso. A volumetria irreverente da edificação está diretamente associada com a capital, Porto e Arte. Apresenta uma estrutura externa no formato de uma espinha dorsal, uma espécie de "Casca", representando o peixe e, uma arquitetura moderna com o uso de concreto protendido e vidros. Espera-se

\footnotetext{
${ }^{1}$ Bacharel em Arquitetura e Urbanismo pelo Centro Universitário de Várzea Grande UNIVAG.

${ }^{2}$ Mestre em Física Ambiental pela Universidade Federal de Mato Grosso.

${ }^{3}$ Graduação em Arquitetura e Urbanismo.
} 
que por meio dessa iniciativa, outras entidades federativas construam, a exemplo desse projeto, arquiteturas com estruturas que tenham relação com cultura e a história de suas regiões.

Palavras-Chave: Porto, lazer, arte, museu, cultura.

\section{INTRODUÇÃO}

De uma maneira geral, nas capitais brasileiras, há certa carência de espaços públicos destinados a abrigar museus, pois, não fazem parte do planejamento urbano, nem estão inseridas no plano de políticas públicas. De acordo com Gehl (2013) a dimensão urbana tem sido apenas um tópico do planejamento urbano, com ênfase a outras questões como, a do aumento do tráfego dos automóveis. O site O Livre (2018) aponta que a falta de uma gestão de qualidade, o não comprometimento do poder público e, a escassez de verbas voltadas para ocupação desses locais afeta diretamente 0 interesse pela cultura.

Espaços culturais como museus, tem grande potencial turístico, são geradores de recursos financeiros, além de, promoverem o desenvolvimento regional. A história cultural e riquezas naturais, de uma determinada região, podem ser amplamente divulgadas, valorizadas e resguardadas, em espaços destinados a museus e centros culturais. 
Figura 01: Mapa da Quantidade de Museus por Unidade de Federação.

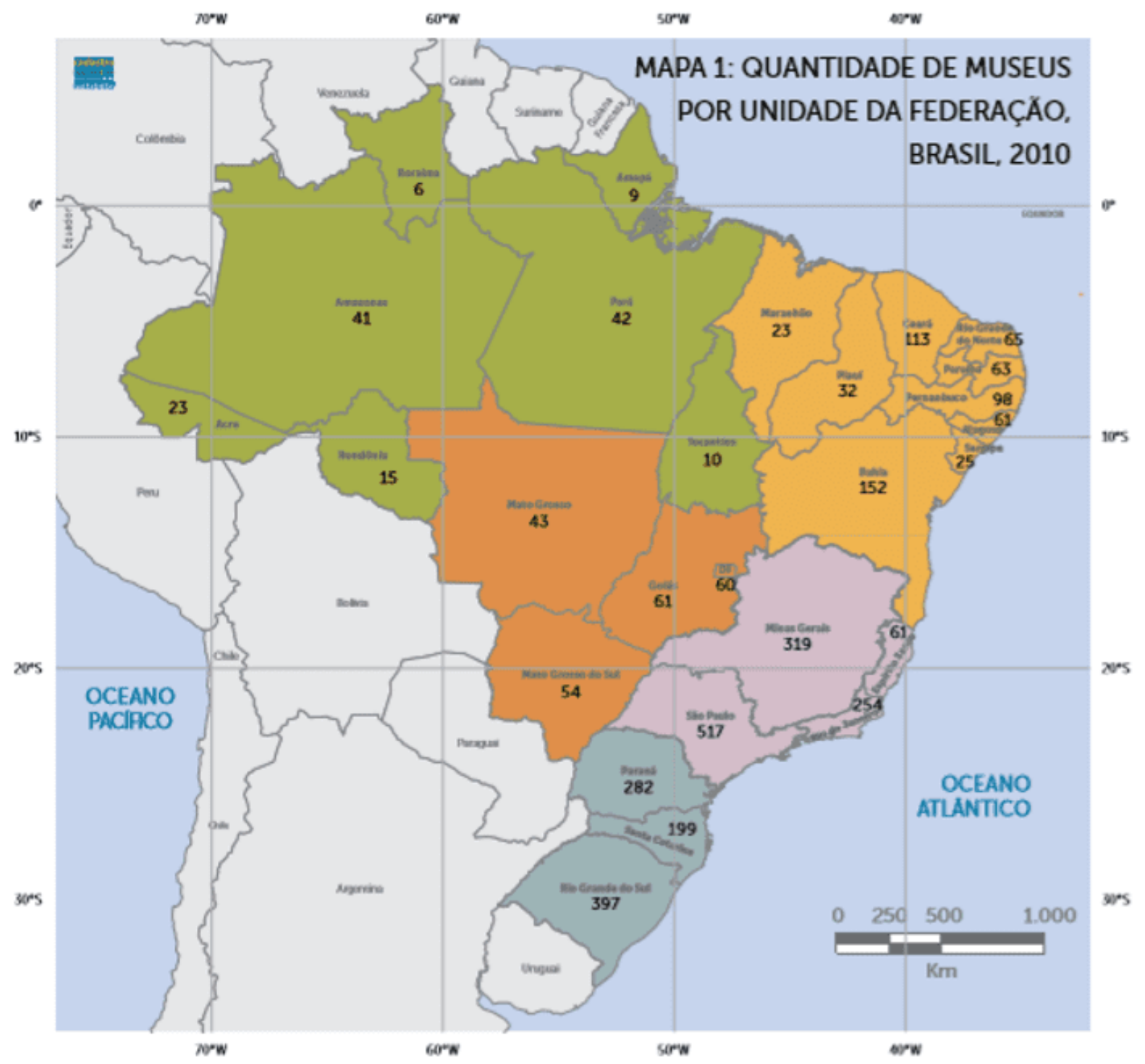

Fonte: Cadastro Nacional de Museus - IBRAM/MINC, 2010

De acordo com a publicação do IBRAM, (Fig. 01) intitulada de Museus em Números Vol. 1 (2011) pode ser observado que, a distribuição destes pelo território brasileiro ocorre de forma desigual. Enquanto que regiões Norte e Centro-Oeste do Brasil abrigam, apenas $12 \%$ de museus, as regiões Sul e Sudeste concentrando $67 \%$ de unidades cadastradas, sugerindo uma maior valorização desse espaço nessas regiões. 
A predominância de museus no litoral do país está associada principalmente densidade populacional, dinâmica econômica e social. Essas regiões apresentam iniciativas culturais abrangentes e acessíveis, criando interesse da população desde a infância. Anico (2005, p.83) aponta que os museus possuem um papel importante no que diz respeito à criação, construção e representação de consciências e identidades pessoais, decorrentes da capacidade que o museu tem de, transmitir informações e conhecimentos de maneira intuitiva e prática, tornando-se um importante instrumento pedagógico e ideológico.

Ainda conforme a publicação do IBRAM, (Tab. 01) na região do Estado de Mato Grosso, são 43 museus cadastrados destes, 20 encontram-se localizados na capital Cuiabá.

Tabela 01. Número de Museus nas capitais do Brasil.

TABELA 01 - NÚMERO DE MUSEUS NAS CAPITAIS, NAS UFs E PORCENTAGEM DE CONCENTRAÇÃO DE MUSEUS NAS CAPITAIS E NO DISTRITO FEDERAL

\begin{tabular}{|c|c|c|c|}
\hline CAPITAL & $\begin{array}{ll}\text { NÚMERO } & \text { DE } \\
\text { MUSEUS } & \text { NA } \\
\text { CAPITAL } & \end{array}$ & $\begin{array}{l}\text { NÚMERO DE } \\
\text { MUSEUS NA } \\
\text { UF }\end{array}$ & \begin{tabular}{l} 
PORCENTAGEM DE \\
CONCENTRAÇÃO \\
DE MUSEUS NAS \\
CAPITAIS \\
RELAÇÃO EM \\
\multicolumn{2}{l}{ TOTAL DA UF $(\%)$}
\end{tabular} \\
\hline Brasil & 923 & 3.025 & 30,5 \\
\hline Sudeste & 307 & 1151 & 26,7 \\
\hline $\begin{array}{l}\text { Belo Horizonte } \\
\text { (MG) }\end{array}$ & 41 & 319 & 12,9 \\
\hline Vitória (ES) & 10 & 61 & 16,4 \\
\hline $\begin{array}{l}\text { Rio de Janeiro } \\
\text { (RJ) }\end{array}$ & 124 & 254 & 48,8 \\
\hline São Paulo (SP) & 132 & 517 & 25,5 \\
\hline
\end{tabular}




\begin{tabular}{|l|l|l|l|}
\hline Sul & $\mathbf{1 6 1}$ & $\mathbf{8 7 8}$ & $\mathbf{1 8 , 3}$ \\
\hline $\begin{array}{l}\text { Curitiba (PR) } \\
\text { Florianópolis }\end{array}$ & 70 & 282 & 24,8 \\
$\begin{array}{l}\text { (SC) } \\
\text { Porto Alegre }\end{array}$ & 63 & 199 & 14,1 \\
$\begin{array}{l}\text { (RS) } \\
\text { Centro-Oeste }\end{array}$ & $\mathbf{1 1 3}$ & 397 & 15,9 \\
\hline $\begin{array}{l}\text { Campo Grande } \\
\text { (MS) }\end{array}$ & 16 & $\mathbf{2 1 8}$ & $\mathbf{5 1 , 8}$ \\
\hline $\begin{array}{l}\text { Cuiabá (MT) } \\
\text { Goiânia (GO) }\end{array}$ & 17 & 54 & 29,6 \\
\hline $\begin{array}{l}\text { Distrito Federal } \\
\text { (DF) }\end{array}$ & 60 & 43 & 46,5 \\
\hline
\end{tabular}

Fonte: Cadastro Nacional de Museus - IBRAM/MINC, 2010.

As iniciativas aplicadas nas regiões litorâneas são fundamentais e, devem ser conduzidas também em outros locais, incentivando a procura por espaços destinados a exposições de arte, amostras e feiras dedicadas à educação e, valorização das culturas regionais e nacionais, integrando o passado ao futuro.

O projeto consiste na implantação de um museu em Cuiabá, para tal, foram elaborados os seguintes questionamentos: Os atuais espaços utilizados para abrigar os museus, apresentam uma arquitetura ou conceito inovador em sua estrutura? Quais são os recursos que deverão ser adotados para tornar os museus, espaços atrativos à população? Entende-se que, o espaço Museu abriga e expõe a arte, além de oferecer oficinas à comunidade, sendo, portanto, um local que valoriza a construção do conhecimento. Além das obras expostas e oficinas oferecidas, destacase também que a arquitetura deve ter formato diferenciado e inovador, características que atraem a curiosidade da população. 


\section{FUNDAMENTAÇÃO TEÓRICA}

\section{ARTE}

Segundo Argan (1989, p. 13) as obras de arte são coisas às quais se relaciona um valor. "pode-se ter preocupação pelas coisas: procurá-las, identificá-las, classificá-las, conservá-las, restaurá-las, exibi-las, comprá-las, vendê-las; ou, então, pode-se ter em mente o valor: pesquisar em que ele consiste, como se gera e se transmite, se reconhece e se usufrui".

Figura 02: Mona Lisa de Leonardo da Vinci.

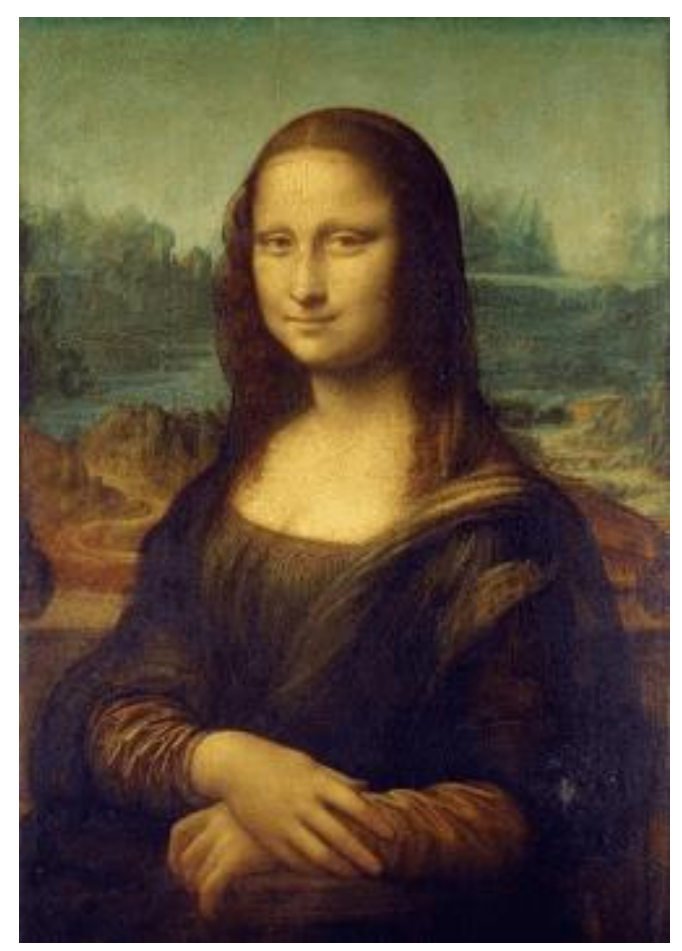

Fonte: Cultura Genial. Acesso em 22 de março de 2019. 
Figura 03: O Grito de Edward Munch.

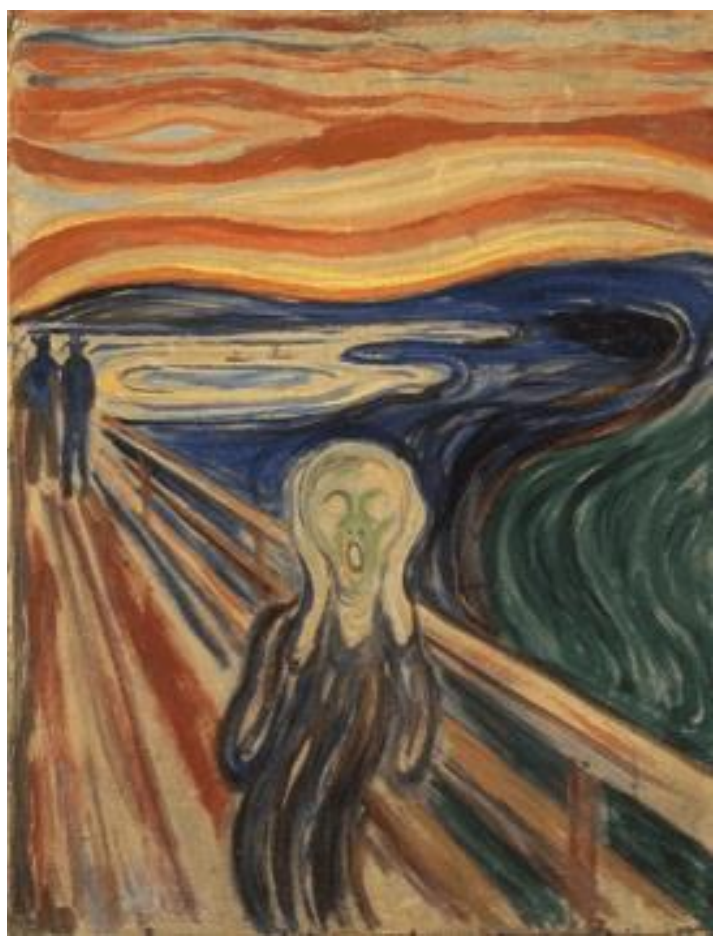

Fonte: Cultura Genial. Acesso em 22 de março de 2019.

Figura 04: Artes e suas ramificações.
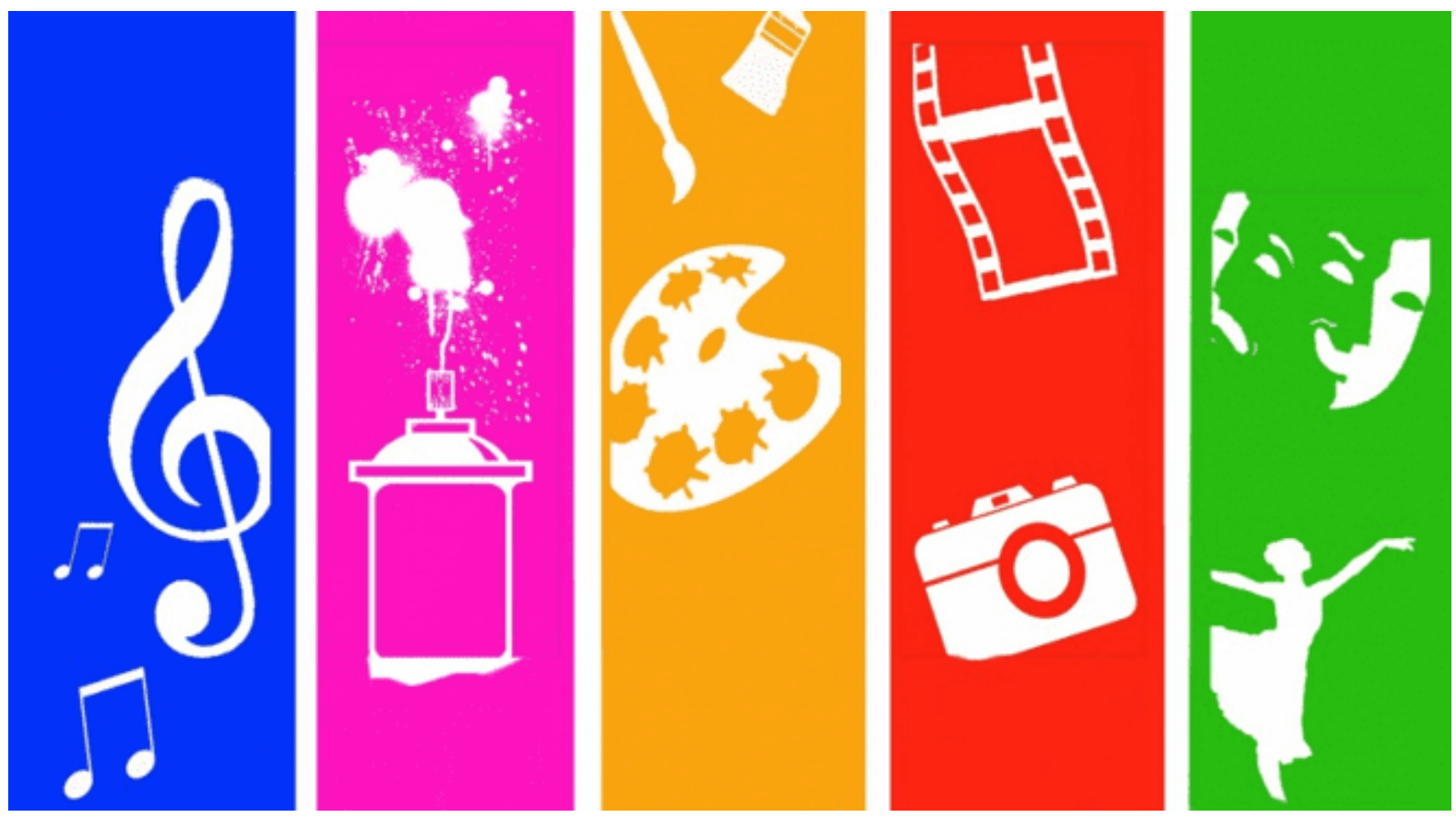

Fonte: Em diálogo. Acesso em 22 de março de 2019.

RC: 43477

Disponível em: https://www.nucleodoconhecimento.com.br/arquitetura/proposta-projetual 
Por meio da arte, o ser humano é capaz de se comunicar, expressar sentimentos e emoções. Sua representatividade se dá por meio de várias vertentes como, pinturas, esculturas, dança, folclore, teatro, música, cinema, arquitetura, entre outras.

A arte congrega lazer e conhecimento, sendo o museu, peça importante na divulgação da cultura e do conhecimento.

\section{MUSEU}

De acordo com o Conselho Internacional de Museus (ICOM) os museus são instituições permanentes e sem fins lucrativos, que exercem seu serviço para com a sociedade e seu desenvolvimento, deve ser uma instituição aberta ao público e que adquire, conserve, pesquise, divulgue e expõe com fins educativos e de lazer. Devem ser testemunhos materiais e imateriais dos povos ali existentes.

Segundo Chagas (1985), museu, é uma ligação entre o passado e o futuro, onde no mesmo deve prevalecer seu caráter social e educativo.

Almandrade (2008) museu, uma edificação capaz de abrigar muito mais que inaugurações de exposições, seu papel é de suma importância na vida urbana e na cultura do País. São importantes instrumentos para a formação cultural de uma sociedade, pois, educam, informam e, preservam a memória de uma cidade ou país.

Segundo Argan (1989) a cidade moderna não se agrega e não funciona sem ser custeada pela cidade antiga, essa ligação entre o moderno e o antigo implica diretamente na história da cidade. Uma vez que se determinem quais edificações serão conservadas na cidade, esses patrimônios históricos deverão ser mantidos e cuidados para a preservação da edificação, história e cultura da cidade e de seus habitantes.

Segundo Argan (1989, p. 242) a arquitetura consiste em tudo que está relacionado à construção, e é com as técnicas da construção que se organiza e projeta edificações ou cidades. $O$ autor explica que "Assim como a pintura é figurativa, a arquitetura é por excelência representativa". A principal tarefa cultural de arquitetos e urbanista nos dias 
atuais é a melhoria e recuperação da cidade, através de metodologias urbanísticas capazes de reerguer e salvar a cidade como instituição histórica sem comprometer sua estruturação existente.

As melhorias atribuídas a arquitetos e suas metodologias urbanísticas, sem dúvida, devem ser aplicadas também em Cuiabá, preservando as estruturas antigas e, ao mesmo tempo, mostrando no moderno as características relevantes da arquitetura e cultura antiga. A construção do espaço "Museu de Arte de Cuiabá", em um local de grande importância histórica para a capital mato-grossense, pretende integrar e preservar todos esses valores além de, ser uma arquitetura moderna que tem preocupação principalmente com o conforto térmico.

A cidade de Cuiabá - MT possui características de um clima quente e seco. Um dos pontos turísticos na região, denominada de Chapada dos Guimarães, formação rochosa que impede o fluxo de ventos, contribui para aumento da elevação das temperaturas, apresentando sempre na capital, sensações térmicas muito altas,

Lamberts et al (1997) ensina que na arquitetura a eficiência energética pode ser entendida como um atributo à edificação, com conforto térmico e baixo consumo de energia.

Para o projeto previsto, serão analisadas e adotadas medidas de eficiência energética, a fim de proporcionar um ambiente agradável com características de sustentabilidade. $\mathrm{Na}$ região de estudo de implantação do projeto, o clima é tropical (Fig. 05) onde, no verão é quente e chuvoso e no inverno, seco e frio. 
Figura 05: Classificação dos climas no Brasil, onde Cuiabá possui a classificação de clima tropical.

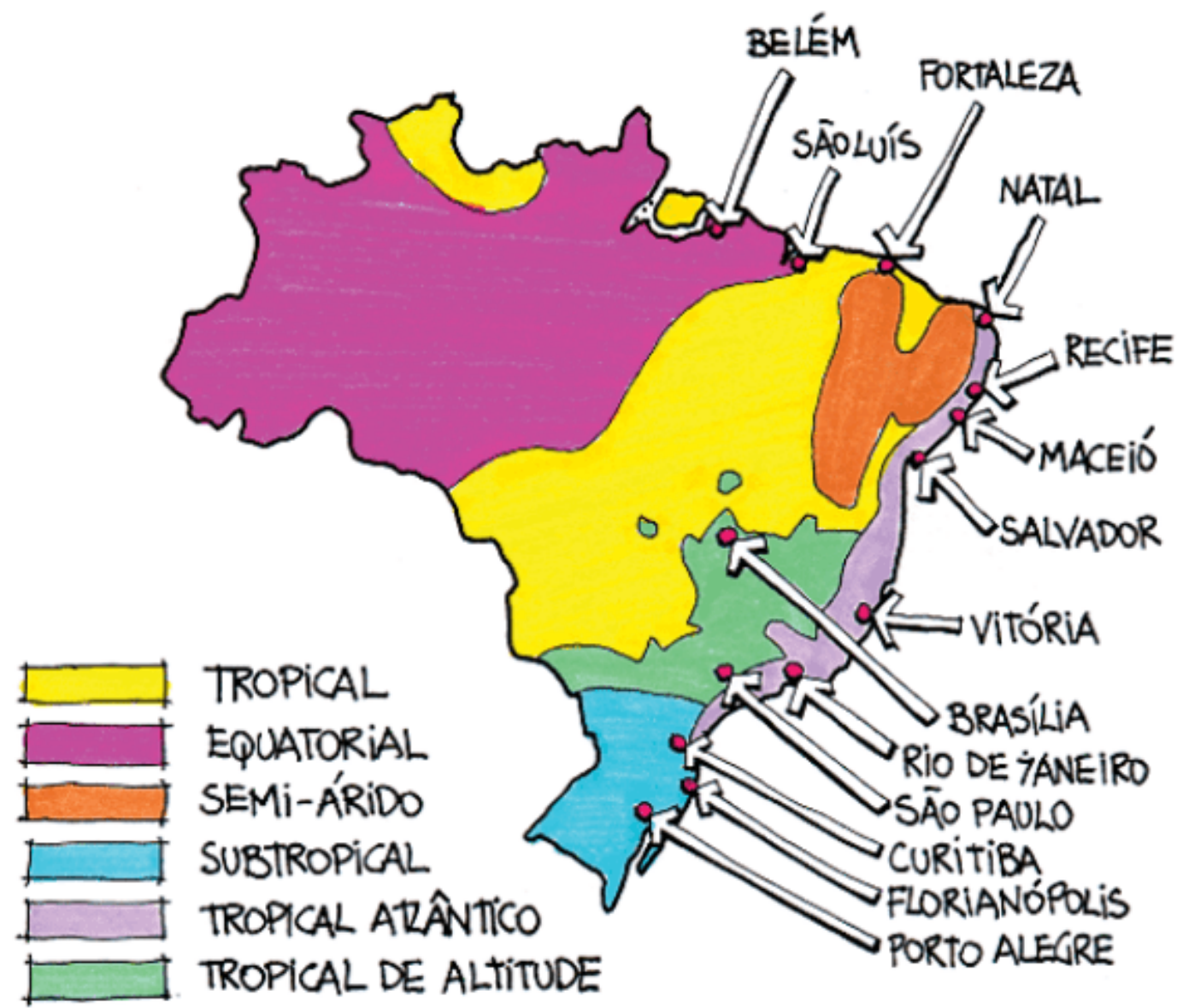

Fonte: Livro Eficiência Energética na Arquitetura (1997).

Lamberts et al (1997, p. 86) esclarece que o "organismo humano pode estar em conforto com diversos limites de umidade relativa (entre 20 e $80 \%$ ) e de temperatura (entre 18 e $29^{\circ} \mathrm{C}$ )," em lugares onde a temperatura fica acima de $20^{\circ} \mathrm{C}$, principalmente próximas à $29^{\circ} \mathrm{C}$, é importante o controle da incidência solar sobre as pessoas, assim evita-se o calor em excesso. 
Figura 06: Zona de Conforto Térmico.

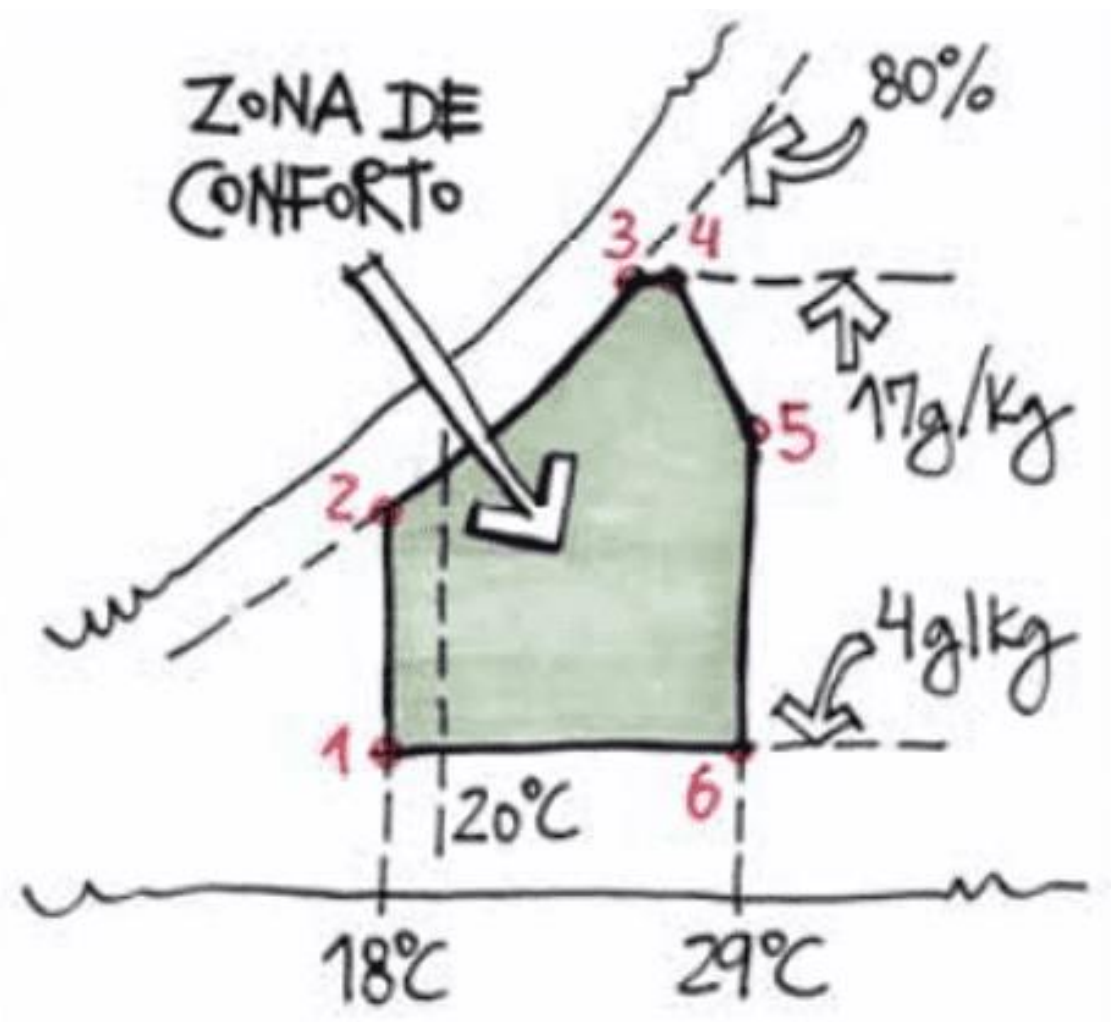

Fonte: Livro Eficiência Energética na Arquitetura (1997).

A Norma Brasileira NBR 15220-3 estabelece o zoneamento bioclimático brasileiro (Fig. 07), subdividindo o país em 8 zonas bioclimáticas. A norma caracteriza e propõe diretrizes construtivas para cada zona em relação ao tamanho das janelas, sombreamento necessário, tipos de paredes e coberturas, além de estratégias bioclimáticas recomendáveis para o local. 
Figura 07: Zoneamento Bioclimático das oito zonas Brasileiras.

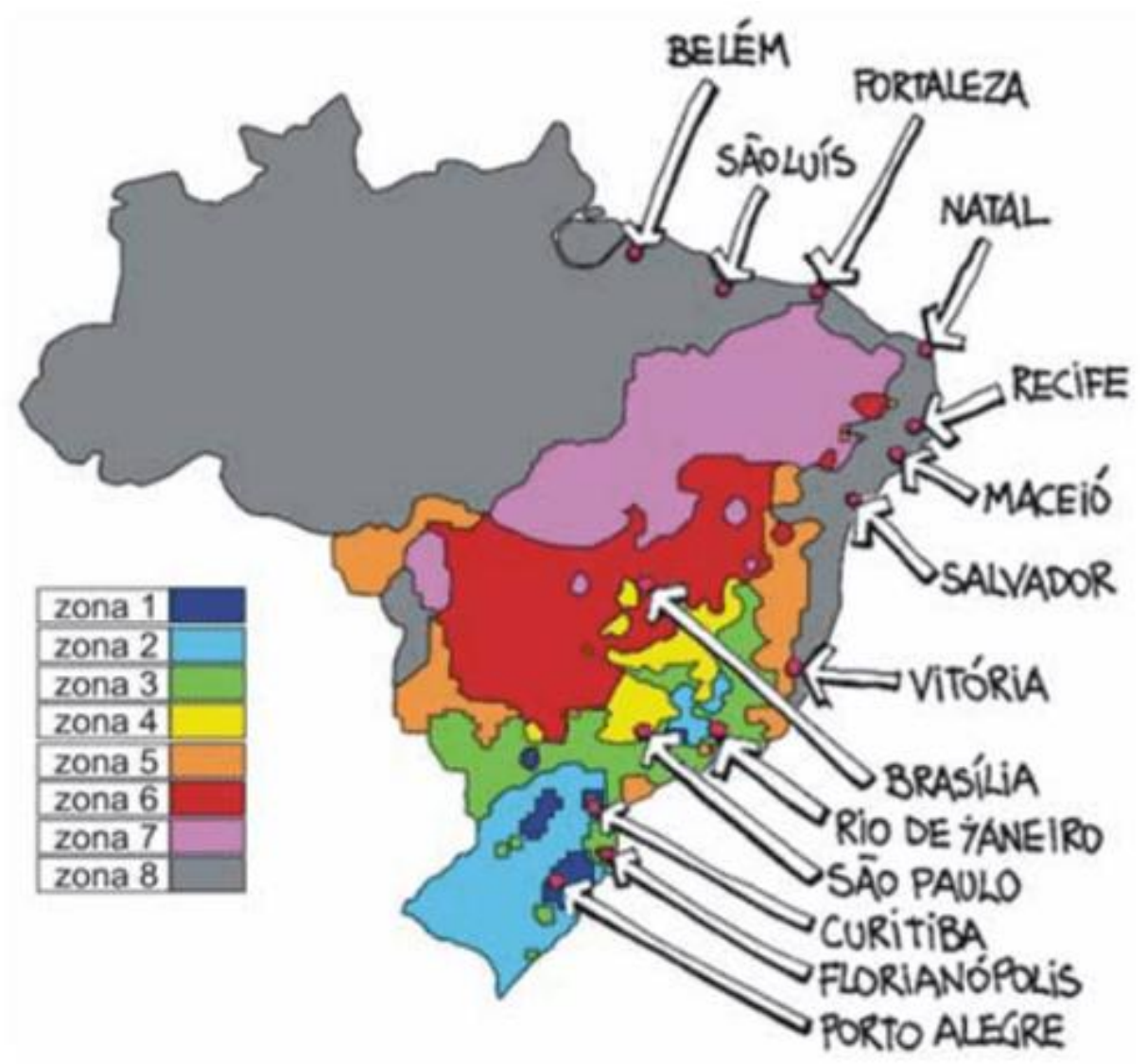

Fonte: Livro Eficiência Energética na Arquitetura (1997).

O projeto em questão encontra-se na zona 7 , onde as recomendações construtivas para Cuiabá incluem o uso de aberturas pequenas e sombreadas o ano inteiro, uso de paredes mais grossas e coberturas pesadas, resfriamento evaporativo, inércia para resfriamento e a ventilação seletiva no verão. 
Figura 08: Ventilação Natural

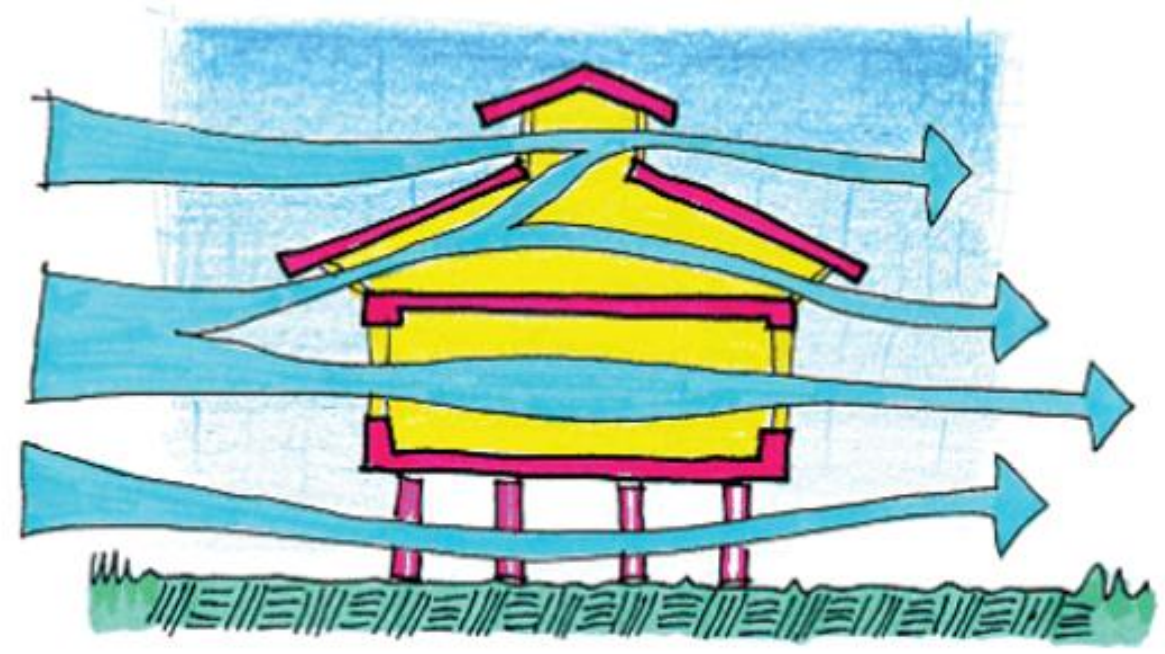

Fonte: Livro Eficiência Energética na Arquitetura (1997).

Os espaços devem ser amplos, evitando barreiras edificadas com grandes alturas, para favorecer a boa distribuição da movimentação do ar (LAMBERTS, DURA, PEREIRA, 1997)

Ainda segundo o autor, o sombreamento é uma das estratégias bioclimáticas mais importantes para o Brasil, que tem clima quente na maior parte do ano em grande parte do seu território. Essa estratégia deve ser utilizada sempre que, a temperatura do ar for superior à $20^{\circ} \mathrm{C}$, mesmo quando a carta bioclimática indicar conforto térmico . 
Figura 9: Linha de sombreamento da Carta Bioclimática.

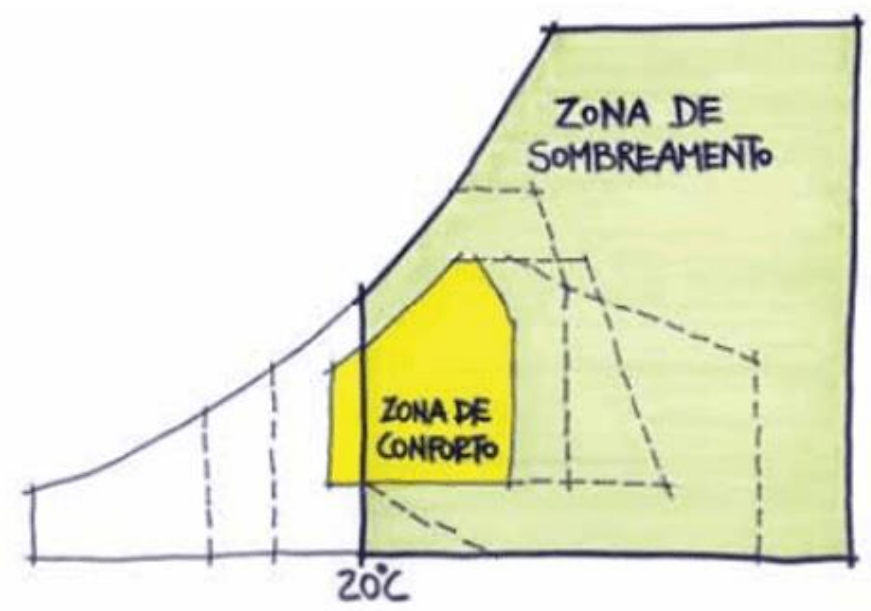

Fonte: Livro Eficiência Energética na Arquitetura (1997).

As principais técnicas de sombreamento são, o uso de proteções sobre brises, beirais de telhado generosos, marquises, sacadas, persianas, venezianas ou outro protetor interno, a orientação adequada do projeto e, o uso de vegetação (LAMBERTS, DURA, PEREIRA, 1997, p. 91)

No Brasil e principalmente em Cuiabá, a principal fonte de calor é a radiação solar, onde sua alta incidência causam desconfortos térmicos.

Figura 10: Árvore e Radiação Solar.

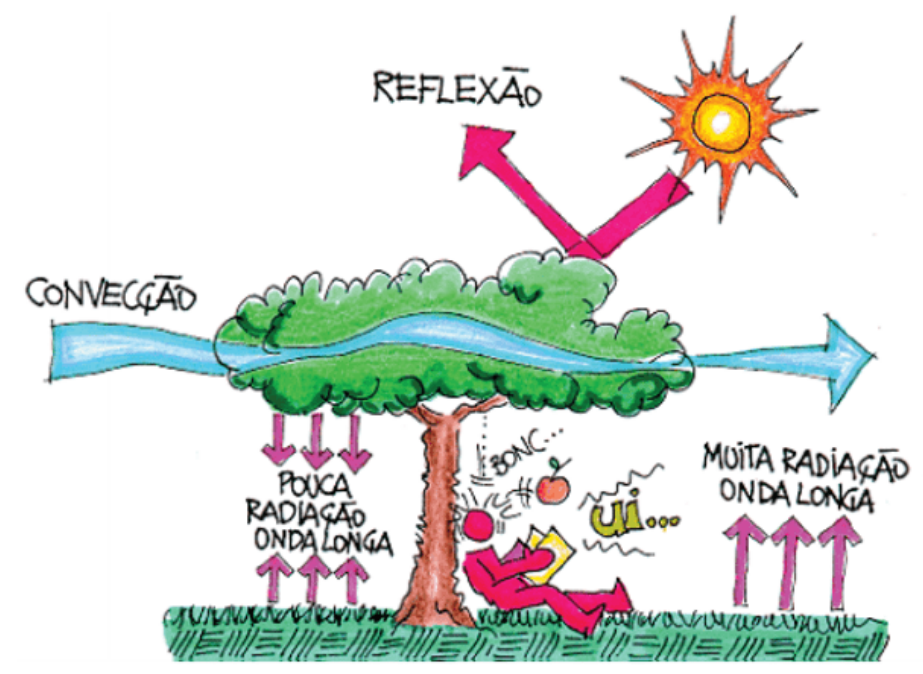


Fonte: Livro Eficiência Energética na Arquitetura (1997).

Um dos principais métodos naturais para se amenizar esses raios solares é a implantação de vegetações, que conseguem absorver parte da radiação solar. A cor também possui uma grande importância plástica na arquitetura, mas sua utilidade vai muito além disso. Cores escuras, aplicadas em superfícies externas absorvem uma maior quantidade de radiação, o oposto ocorre com as cores claras Lamberts et al (1997).

O vidro, é Outro isolante importante a ser empregado em um projeto. Dependerá da necessidade de luz natural e do desempenho térmico do sistema de abertura. São vários os tipos de vidros disponíveis para controlar as perdas ou ganhos de calor, as películas que são absorventes e reflexivos, os duplos ou triplos com tratamento de baixa emissividade, os espectralmente seletivos e entre outros.

Figura 11: Vidro Duplo, sua principal função é o isolamento térmico.

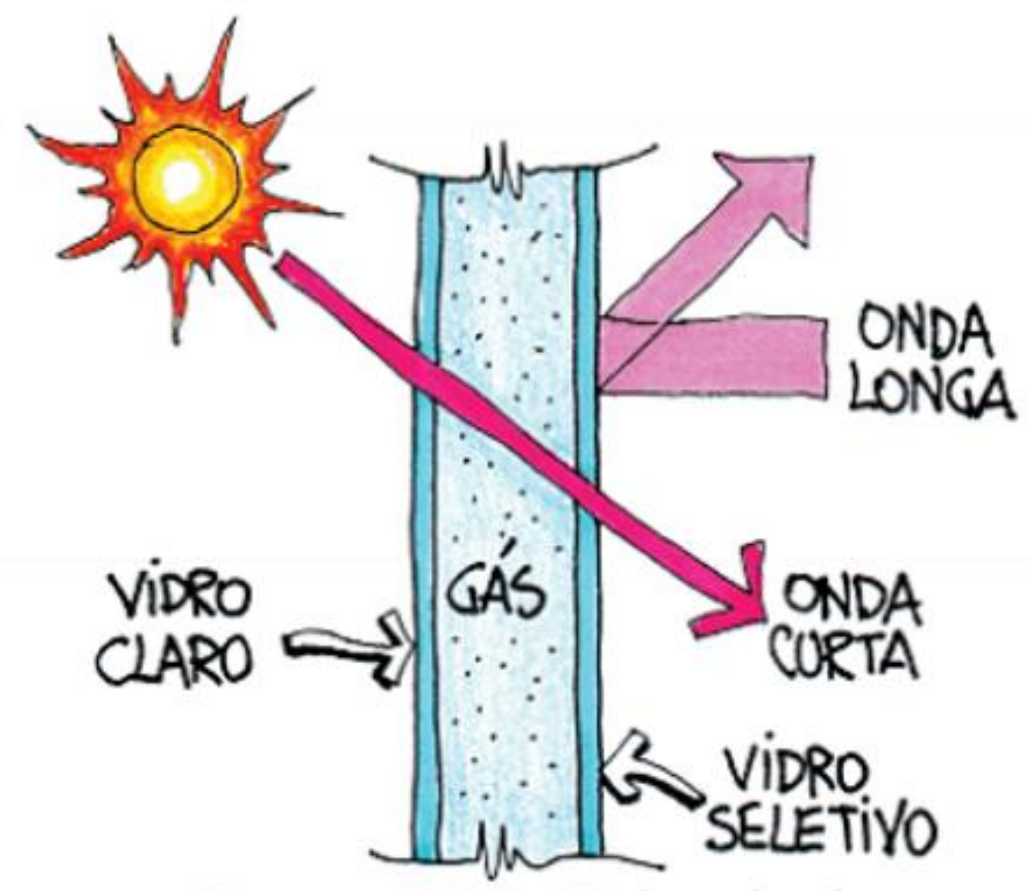

Fonte: Livro Eficiência Energética na Arquitetura (1997).

De acordo com o site Hometeka, outro importante material são as telhas termoacústica (sanduiche). É uma ótima opção para isolamento térmico em edificações, isola a 
temperatura ambiente e o som. É composta por duas chapas metálicas, de aço galvanizado ou galvalume. As telhas contem um isolante em seu interior, geralmente feito de EPS ou PUR. Sua composição é de telha metálica + isolante + telha metálica; é a partir dessa composição que a telha tornou-se conhecida também pelo nome 'sanduíche'.

Figura 12: Estrutura de uma telha Termoacústica.

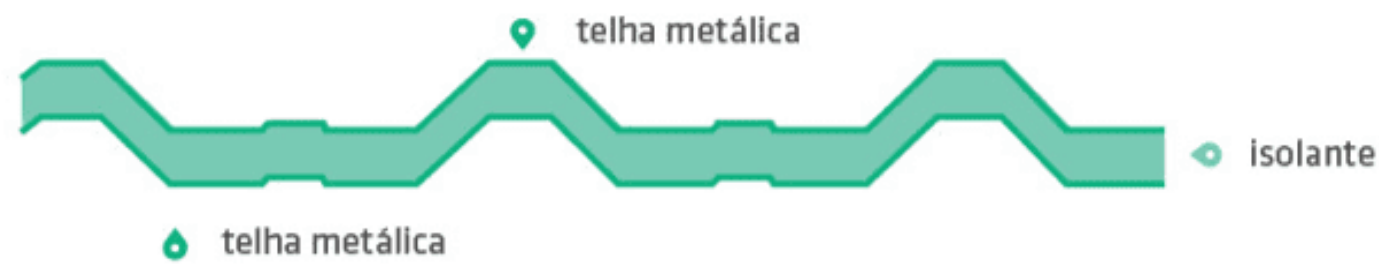

Fonte: Hometeka. Acesso em 29 de março de 2019.

As telhas termoacústicas são consideradas econômicas, reduzindo o uso de equipamentos destinados à refrigeração.

\section{PROJETOS REFERENCIAIS}

Cada projeto escolhido possui um diferencial e retrata o que cada região necessita de acordo com seus princípios e culturas, ambos localizam-se em lugares estratégicos na cidade e valorizam o local onde se inserem. O Museu do Amanhã com sua arquitetura e sustentabilidade possibilitou uma criação única e inovadora na região; o MASP foi um marco e uma referência para sua época, seu vão de 70 metros tornouse o maior vão livre da América Latina durante anos, hoje a edificação permanece sendo um ícone para a cidade de São Paulo. 
Figura 13: Museu do Amanhã.

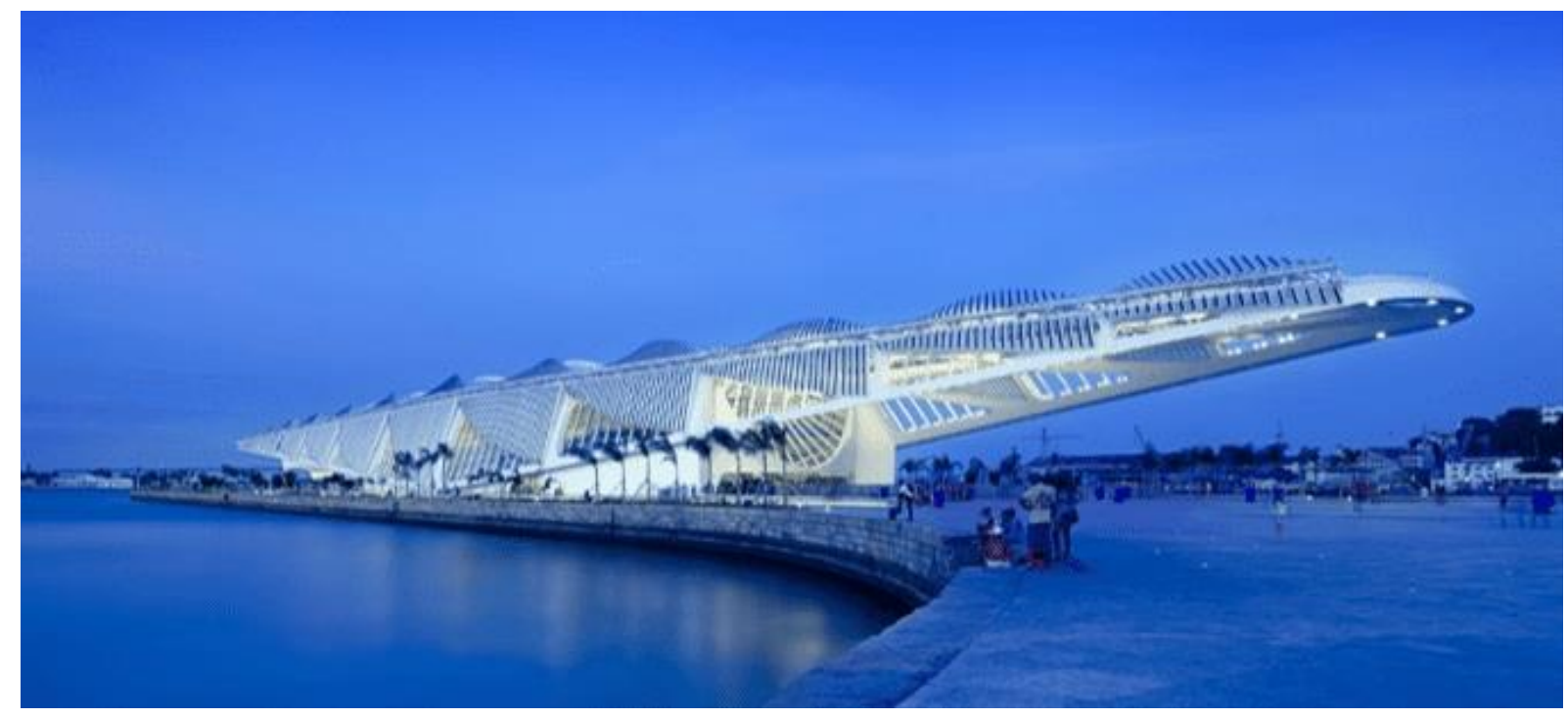

Fonte: Archdaily. Acesso em 22 de março de 2019.

O projeto do Museu do Amanhã é inspirado na cultura carioca e através de sua arquitetura explora a relação entre a cidade e o meio ambiente. $O$ museu possui um espaço de exposições temporárias e permanentes de $5.000 \mathrm{~m}^{2}$, uma praça com $7.600 \mathrm{~m}^{2}$ envolvendo toda a estrutura que se estende ao longo do cais.

Justificativa da Escolha: A escolha deste projeto de referência se deu pelas novas experiências que são vividas dentro da edificação, e com o conhecimento transmitido através das artes que se abriga o Museu, pode-se informar e educar as gerações futuras e a própria sociedade. 
Figura 14: MASP - Museu de Arte de São Paulo.

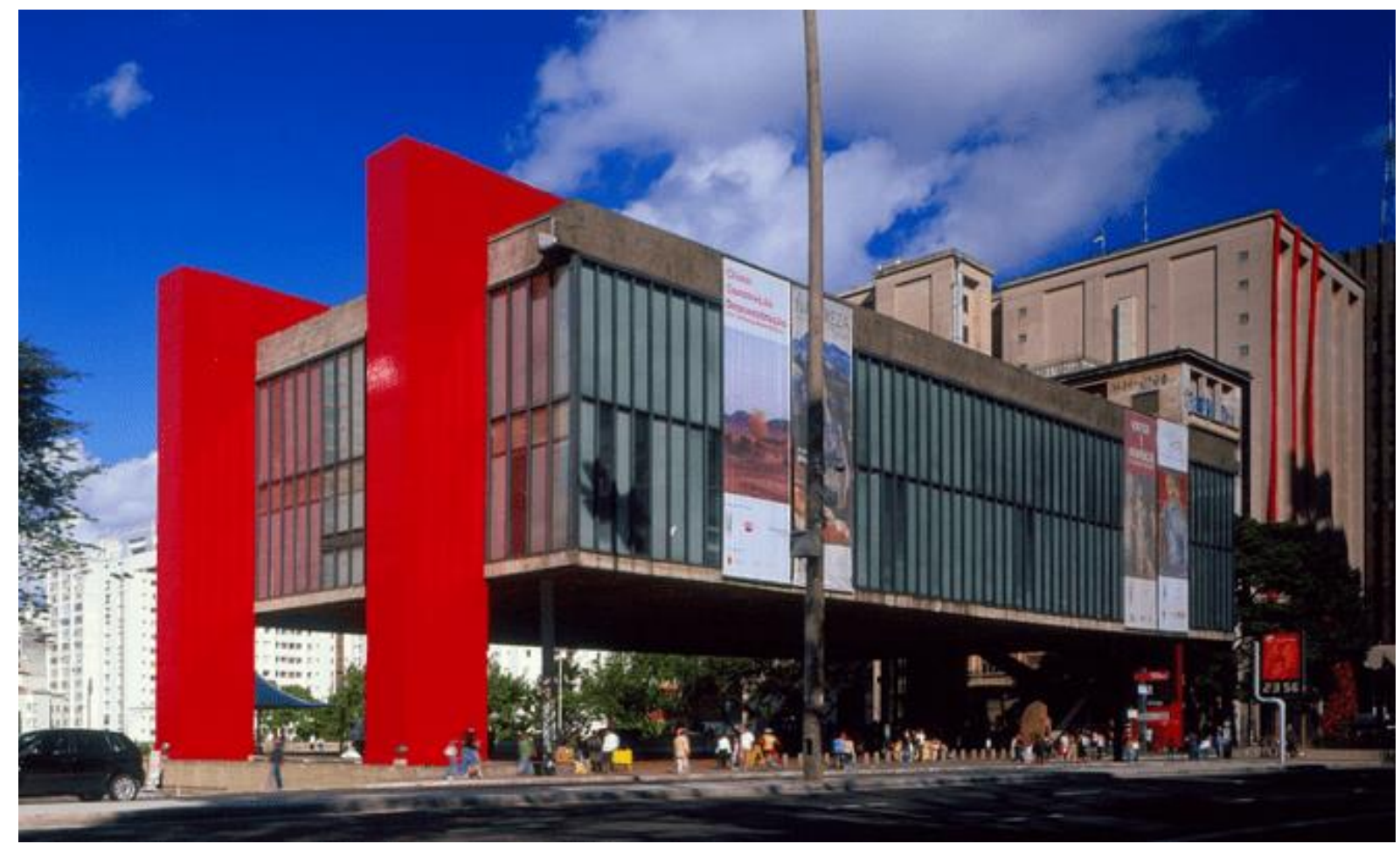

Fonte: Archdaily. Acesso em 22 de março de 2019.

A edificação tem aproximadamente 10 mil metros quadrados. Sua base constitui uma grande praça. Nela está um extenso hall público, palco de reuniões públicas e políticas, um teatro-auditório e um auditório com sala de projeção. A ideia do vazio do pátio, de ar, se relaciona com a forma de exposição dentro do museu, expressando também um conceito de tempo no qual o público é quem gere e domina o espaço.

Justificativa da Escolha: A escolha deste projeto de referência se deu pela sua imponência para a cidade de São Paulo, sendo uma edificação marcante pela sua funcionalidade e lazer proporcionado à população. 
Figura 15: Museu The Broad.

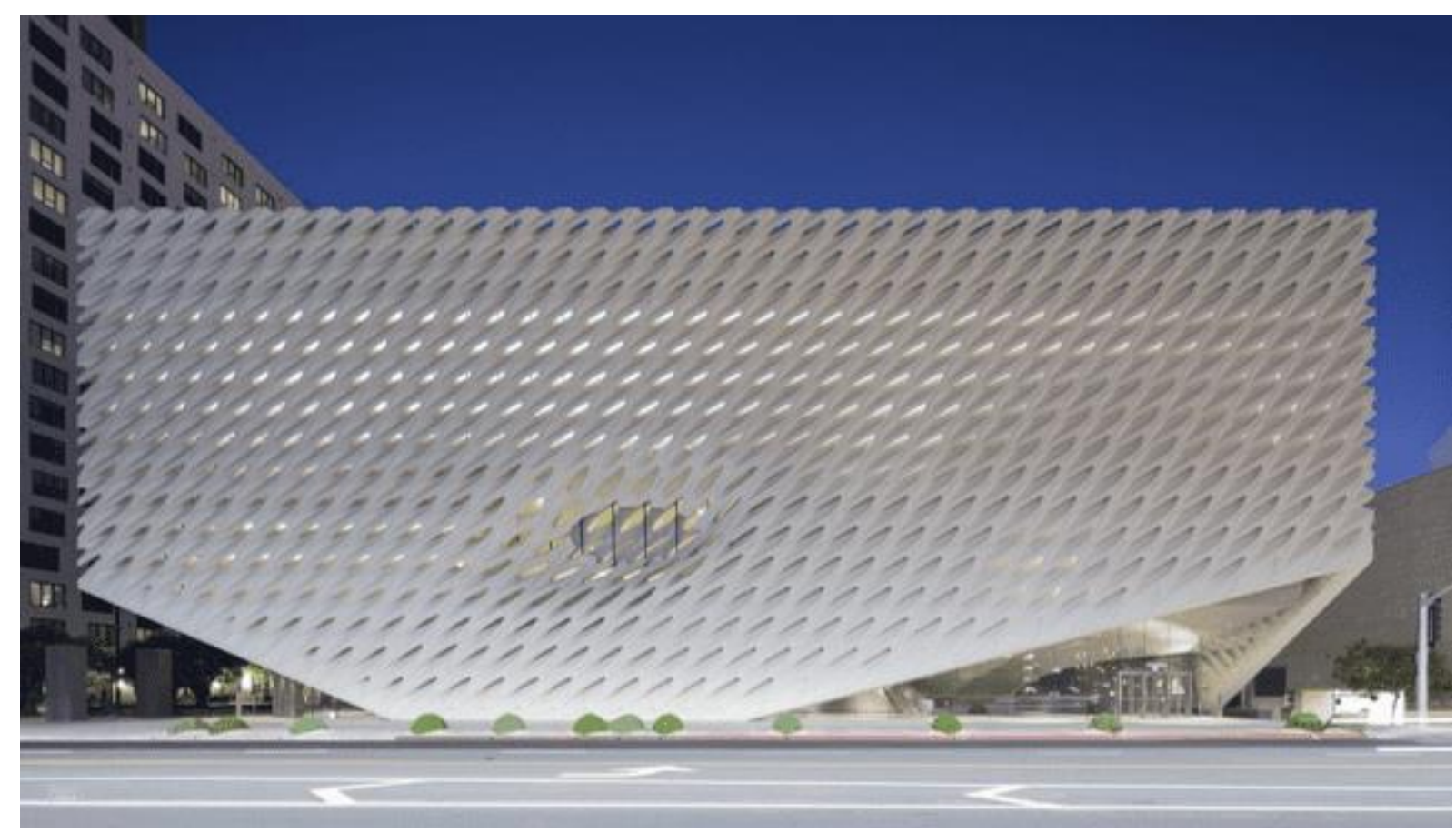

Fonte: Archdaily. Acesso em 22 de março de 2019.

O The Broad é um museu de arte contemporânea, construído no centro de Los Angeles, foi projetado por Diller Scofidio + Renfro, abrigará cerca de 2.000 obras de arte The Broad Art Foundation e das coleções pessoais dos donos, com um dos acervos mais proeminentes do mundo da arte do pós-guerra e contemporânea.

Justificativa da Escolha: A edificação por si só já é uma obra de arte, os componentes externos "véu e cofre" destacam o Museu, com técnicas inovadoras que transmitem sensações únicas ao observador, como principal referência deste projeto para a incorporação da proposta seria uma estrutura que "abriga" a edificação principal, tendo como principal função não somente a estética mas também funcionalidade.

\section{MATERIAIS E MÉTODOS}

Este trabalho propõe a criação de um museu de arte para Cuiabá, sendo um projeto que atenda os interesses da população, com uma arquitetura inovadora e 
principalmente, que seja um exemplo de empreendimento responsável na ocupação espaços públicos ociosos.

\section{ESTUDO DO ENTORNO}

O terreno escolhido para a implantação do projeto possui 12.366,33 m² e está situado no Bairro do Porto em Cuiabá, próximo do Rio Cuiabá, limite natural entre os municípios de Cuiabá e Várzea Grande.

Figura 16: Entorno do Terreno.

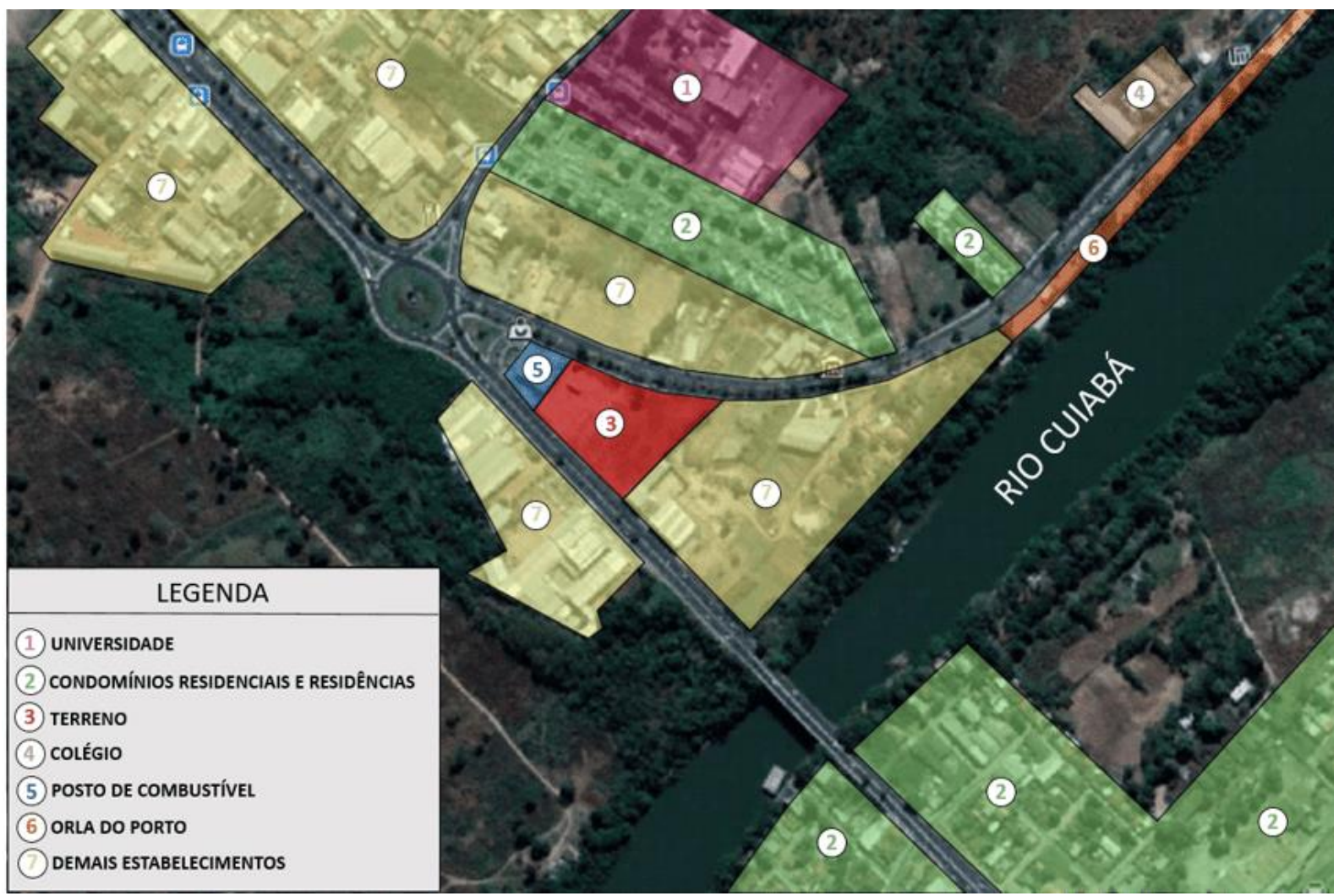

Fonte: Elaborado pela autora, 2019.

$\mathrm{Na}$ figura 16, encontra-se indicado em vermelho a área onde será implantado o projeto, identificado na legenda pelo número 3. Será limitado por duas avenidas principais de acesso, Miguel Sutil, que corta boa parte da capital e, Avenida Manoel José de Arruda, conhecida popularmente como Av. Beira Rio. 


\section{TOPOGRAFIA}

De acordo com dados gerados através do software Global Mapper, foram obtidas as cotas de nível para o terreno, variando de 155,0 m e 159,0 m representando relevo pouco acidentado, não tendo sido necessária modificação em sua topografia.

Figura 17: Curvas de Nível geradas pelo software Global Mapper.

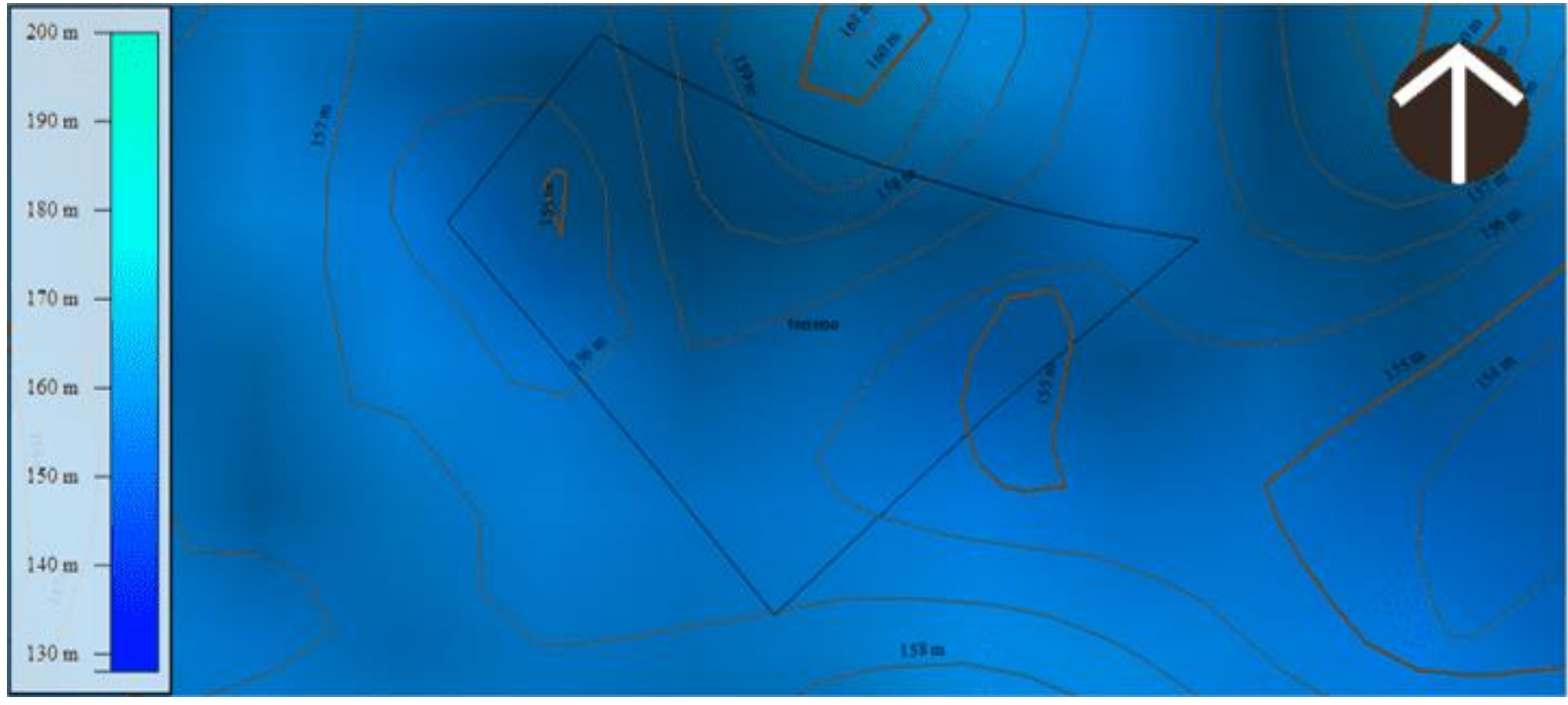

Fonte: Global Mapper, adaptado pela autora, 2019.

Figura 18: Topografia do terreno e mapa de Altimetria.
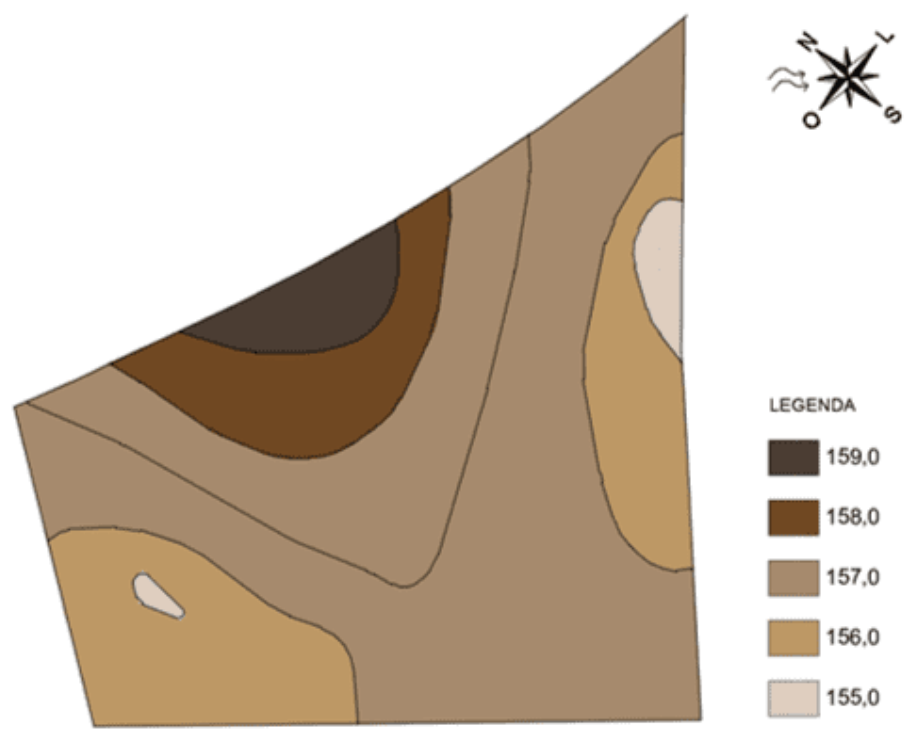

LEGENDA

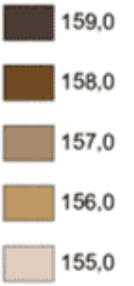


Fonte: Elaborado pela autora, 2019.

Os níveis mais baixos do terreno estão representados pelas cores mais claras, já os níveis mais altos são representados por cores mais escuras.

\section{INSOLAÇÃO}

Figura 19: Estudo de Insolação.

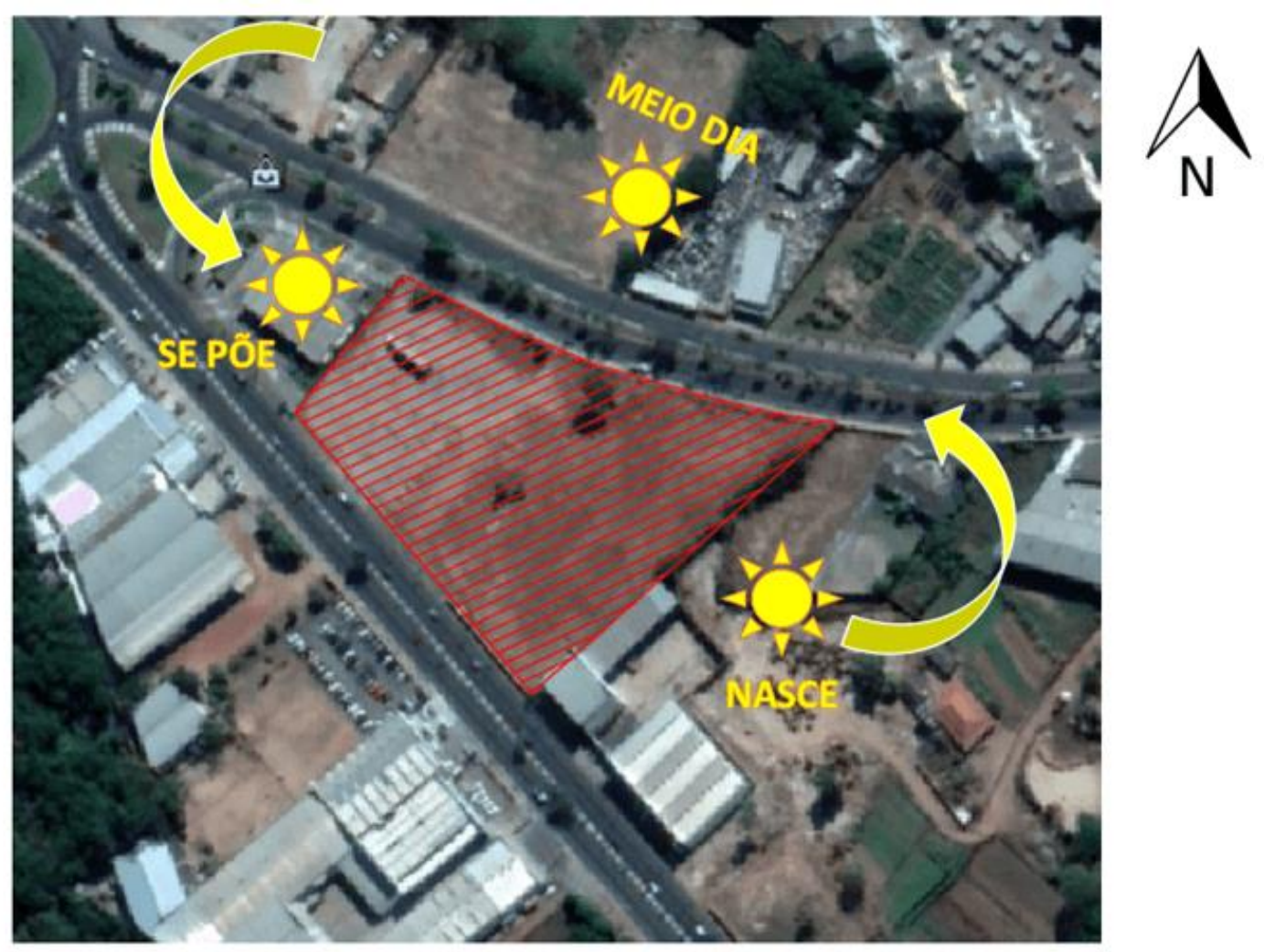

Fonte: Elaborado pela autora, 2019.

A figura 19 mostra o posicionamento do sol a nascente (leste) e ao poente (Oeste), dados que permitiram elaborar estudo técnico sobre insolação, objetivando melhorar o item "conforto térmico" relacionado ao projeto. 


\section{CLIMA}

De acordo com o site INEP (2019) o clima predominante da capital é Tropical, com temperaturas médias anuais de $25,9 \stackrel{\circ}{\circ}$, possuindo a umidade relativa do ar de $60 \%$, predominando entre os meses de julho e agosto.

\section{VEGETAÇÃO}

Figura 20: Situação atual do terreno.

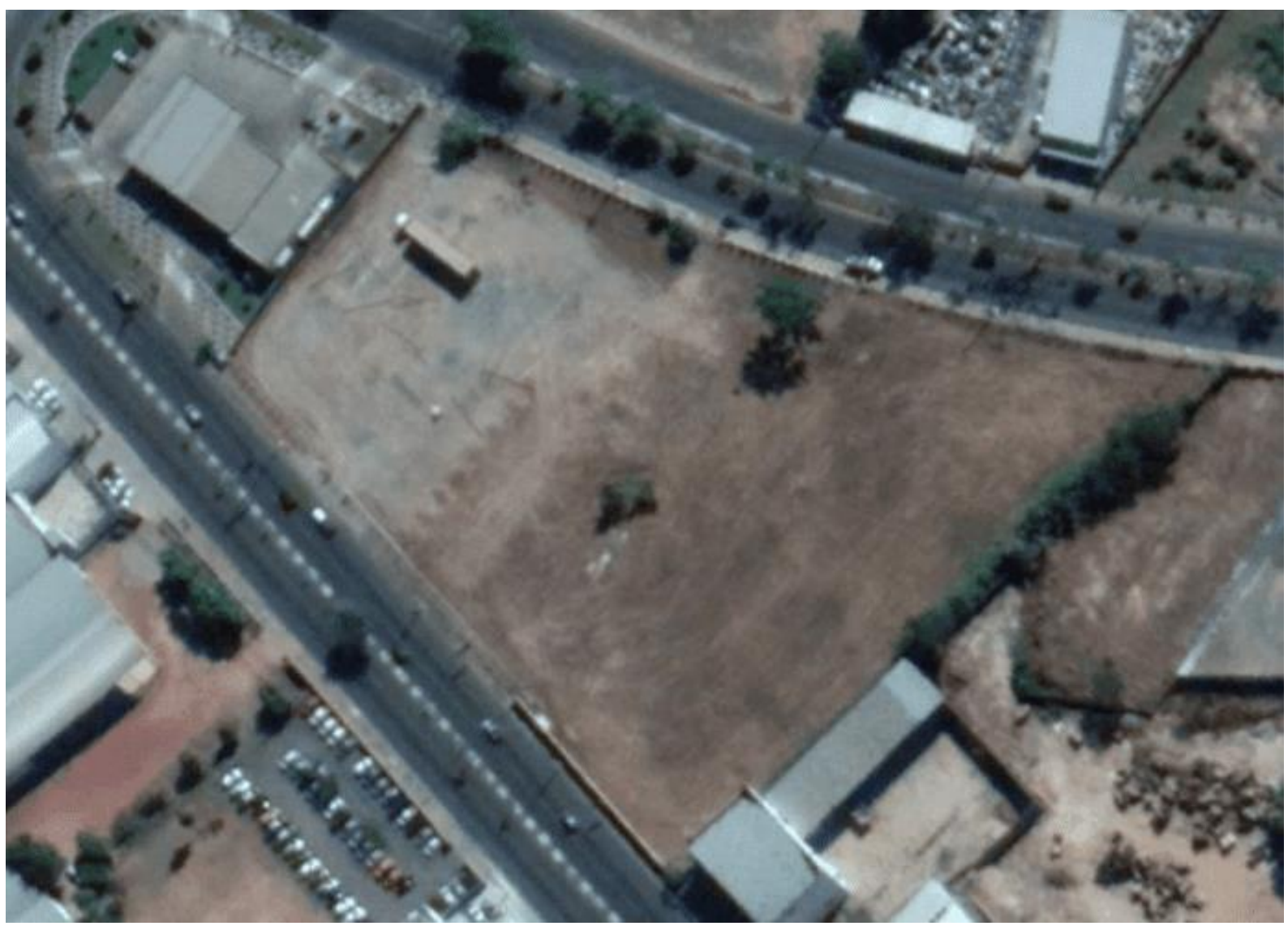

Fonte: Google Eath Pro, 2019.

A vegetação predominante na região é de cerrado, havendo necessidade de arborização quando da implantação do projeto. Foram dispostas árvores de pequeno à médio porte nas laterais da edificação, para que a mesma não bloqueiem a arquitetura da edificação. As arborizações de grande porte foram dispostas nas laterais do terreno para manter a visão panorâmica da fachada. 
A tabela 02 mostra as espécies usadas na proposta com descrição do nome popular, científico e porte.

Tabela 02: Tabela de paisagismo utilizada no projeto.

\begin{tabular}{|c|c|c|c|}
\hline \multicolumn{4}{|c|}{ PAISAGISMO } \\
\hline FIGURA & NOME POPULAR & NOME CIENTIFICO & $\underline{\text { PORTE }}$ \\
\hline & JASMIN-MANGA & PLUMERIA RUBRA & $4,70 \AA \quad \mathrm{m}$ \\
\hline & CHUVA-DE-OURO & CASSIA FISTULA & $4,70 \AA 12 \mathrm{~m}$ \\
\hline & ACEROLA & MALPIGHIA EMARGINATA & $2,40 \AA \mathrm{A}$ \\
\hline & JABUTICABA & MYRCIARIA CAULIFLORA & $4,70 \AA 12 \mathrm{~m}$ \\
\hline
\end{tabular}

Fonte: Elaborado pela autora, 2019.

\section{PROJETO - PARTIDO ARQUITETÔNICO}

Figura 21: Partido arquitetônico da proposta.

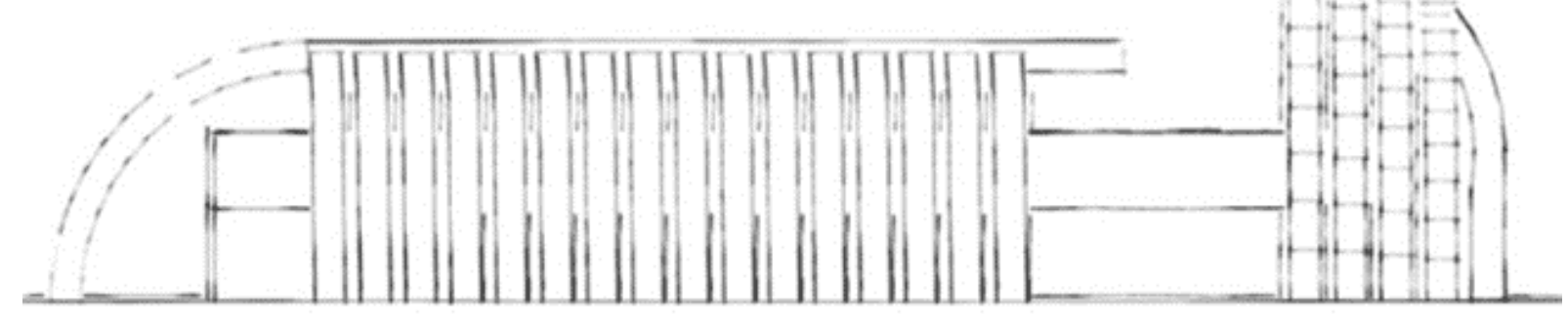

Fonte: Elaborado pela autora, 2019. 


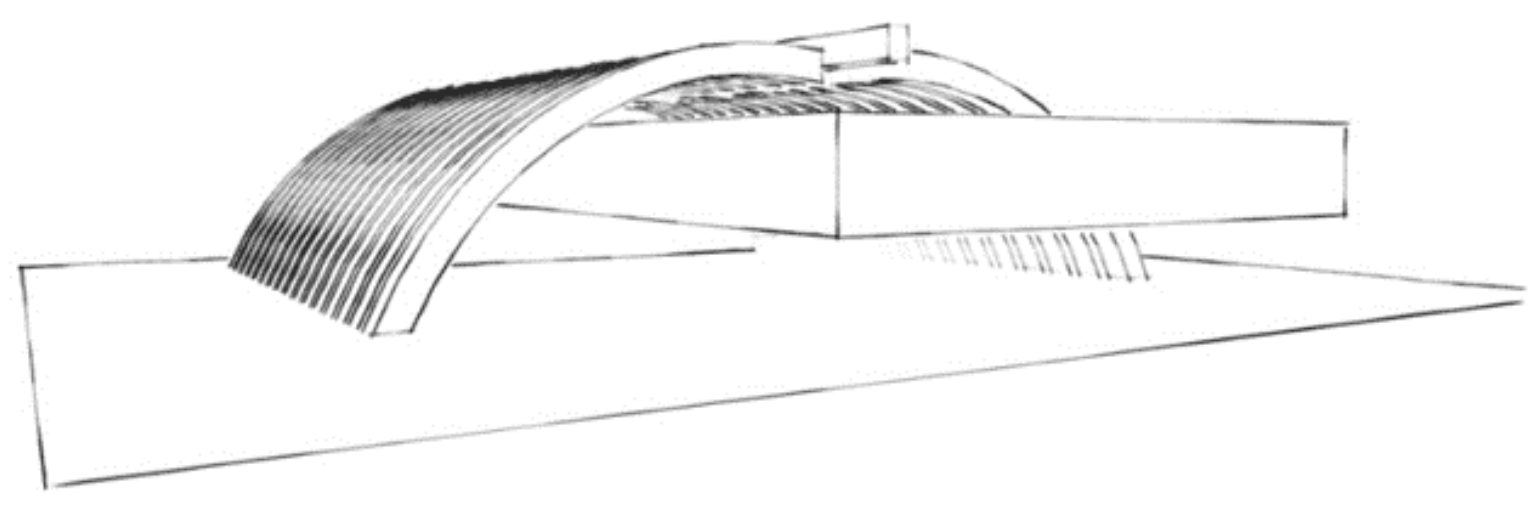

Fonte: Elaborado pela autora, 2019.

O projeto obteve como partido arquitetônico inspiração nas imagens iconográficas representativas para Cuiabá e Mato Grosso, como inserção de referências foram escolhidas a arquitetura indígena e a escama do peixe, inseridos de forma funcional e estética na proposta, onde até sua localização (Bairro do Porto) foi de extrema importância para o partido. A tipologia do MASP, com sua viga vencendo um grande vão e propondo um pátio coberto foi incorporada ao projeto, tendo como objetivo ser um ponto de encontro da população local e visitantes.

\section{ANÁLISE DA LEGISLAÇÃO INCIDENTE}

Os índices urbanísticos são necessários e diferenciados para cada Zona urbana em que o projeto se insere. $O$ art. 150 da Lei Complementar no 249/11 possui uma tabela que define os índices de acordo com as Zonas Urbanas.

\begin{tabular}{|c|c|c|c|c|c|c|c|c|}
\hline \multicolumn{9}{|c|}{ Índices Urbanísticos } \\
\hline $\begin{array}{l}\text { Zon } \\
\text { as }\end{array}$ & $\begin{array}{l}\text { Coef. } \\
\text { de } \\
\text { Ocup } \\
\text { a-ção } \\
\text { (CO) }\end{array}$ & $\begin{array}{l}\text { Cobert } \\
\text { ura } \\
\text { vegetal } \\
\text { paisagí } \\
\text { s-tica } \\
\text { (CVP) }\end{array}$ & $\begin{array}{l}\text { Cobert } \\
\text { ura } \\
\text { Vegetal } \\
\text { Arbôre } \\
\text { a }\end{array}$ & $\begin{array}{l}\text { Coef. de } \\
\text { permea } \\
\text { bili-dade }\end{array}$ & $\begin{array}{l}\text { Potencia } \\
\text { I } \\
\text { Construt } \\
\text { ivo (PC) }\end{array}$ & $\begin{array}{l}\text { Limite } \\
\text { de } \\
\text { Adens } \\
\text { a- } \\
\text { mento } \\
\text { (LA) }\end{array}$ & $\begin{array}{l}\text { Potencia } \\
\text { I } \\
\text { Construt } \\
\text { ivo } \\
\text { Exceden } \\
\text { te }\end{array}$ & $\begin{array}{l}\text { Gabari } \\
\text { to de } \\
\text { Altura }\end{array}$ \\
\hline ZEX & 0,15 & [1] & 0,85 & 0,85 & 0,15 & 0,15 & 0,00 & - \\
\hline
\end{tabular}


CONHECIMENTO https://www.nucleodoconhecimento.com.br

\begin{tabular}{|c|c|c|c|c|c|c|c|c|}
\hline ZUM & 0,50 & 0,20 & 0,05 & 0,25 & 1,00 & 2,00 & 1,00 & - \\
\hline ZPR & 0,50 & 0,20 & 0,05 & 0,25 & 1,00 & 2,00 & 1,00 & - \\
\hline ZC & 0,80 & 0,20 & - & 0,20 & 2,00 & 3,00 & 1,00 & - \\
\hline ZCR & 0,80 & 0,20 & - & 0,20 & 2,00 & 3,00 & 1,00 & - \\
\hline ZIH & 0,80 & 0,20 & - & 0,20 & 3,00 & 3,00 & 0,00 & - \\
\hline $\begin{array}{l}\text { ZIA } \\
1\end{array}$ & 0,15 & 0,20 & 0,50 & 0,70 & 1,00 & 1,00 & 0,00 & - \\
\hline $\begin{array}{l}\text { ZIA } \\
2\end{array}$ & 0,05 & 0,05 & 0,85 & 0,90 & 0,50 & 0,50 & 0,00 & - \\
\hline $\begin{array}{l}\text { ZIA } \\
3\end{array}$ & 0,05 & 0,00 & 0,95 & 0,95 & 0,10 & 0,10 & 0,00 & - \\
\hline $\begin{array}{l}\text { ZAM } \\
1\end{array}$ & $0,50^{*}$ & [2] & [2] & [2] & [2] & [2] & [2] & 12,00 \\
\hline $\begin{array}{l}\text { ZAM } \\
2\end{array}$ & $0,50^{*}$ & [2] & [2] & [2] & [2] & [2] & [2] & 24,00 \\
\hline $\begin{array}{l}\text { ZEIS } \\
1\end{array}$ & 0,70 & 0,20 & - & 0,20 & 2,00 & 2,00 & 0,00 & - \\
\hline $\begin{array}{l}\text { ZEIS } \\
2\end{array}$ & 0,70 & 0,20 & - & 0,20 & 1,00 & 1,00 & 0,00 & - \\
\hline $\begin{array}{l}\text { ZER } \\
\text { E }\end{array}$ & 0,70 & 0,20 & - & 0,20 & 1,00 & 1,00 & 0,00 & - \\
\hline $\begin{array}{l}\text { ZCT } \\
\text { R } 1\end{array}$ & 0,75 & 0,20 & 0,05 & 0,25 & 3,00 & 6,00 & 3,00 & - \\
\hline $\begin{array}{l}\text { ZCT } \\
\text { R } 2\end{array}$ & 0,70 & 0,20 & 0,05 & 0,25 & 2,00 & 4,00 & 2,00 & - \\
\hline $\begin{array}{l}\text { ZCT } \\
\text { R } 3\end{array}$ & 0,65 & 0,20 & 0,05 & 0,25 & 2,00 & 4,00 & 2,00 & - \\
\hline ZAI & 0,40 & 0,30 & 0,20 & 0,25 & 1,00 & 1,00 & 0,00 & - \\
\hline ZTC & [2] & [2] & [2] & [2] & [2] & [2] & [2] & $\begin{array}{l}\text { Arts. } \\
160 \text { e } \\
161\end{array}$ \\
\hline
\end{tabular}


Tabela 03: Índices Urbanísticos. Fonte: Lei de Uso, Ocupação e Urbanização do Solo de Cuiabá.

O Terreno está localizado na Zona de Corredor de Tráfego 1- ZCTR1. De acordo com o percentual da Tabela de Zoneamento Urbano foram obtidos os resultados dos índices do terreno, onde:

- Coeficiente de Ocupação: 9.274,74 m²

- Cobertura Vegetal Paisagística: $2.473,26 \mathrm{~m}^{2}$

- Cobertura Vegetal Arbórea: $618,31 \mathrm{~m}^{2}$

- Coeficiente de Permeabilidade: $3.091,58 \mathrm{~m}^{2}$

\section{ENSAIOS TÉCNICOS}

A composição espacial da edificação acontece de forma centralizada no terreno, permitindo que as pessoas que transitam por ambas as vias, tenham uma visão ampla e volumétrica do projeto.

Figura 22: Composição espacial da edificação.

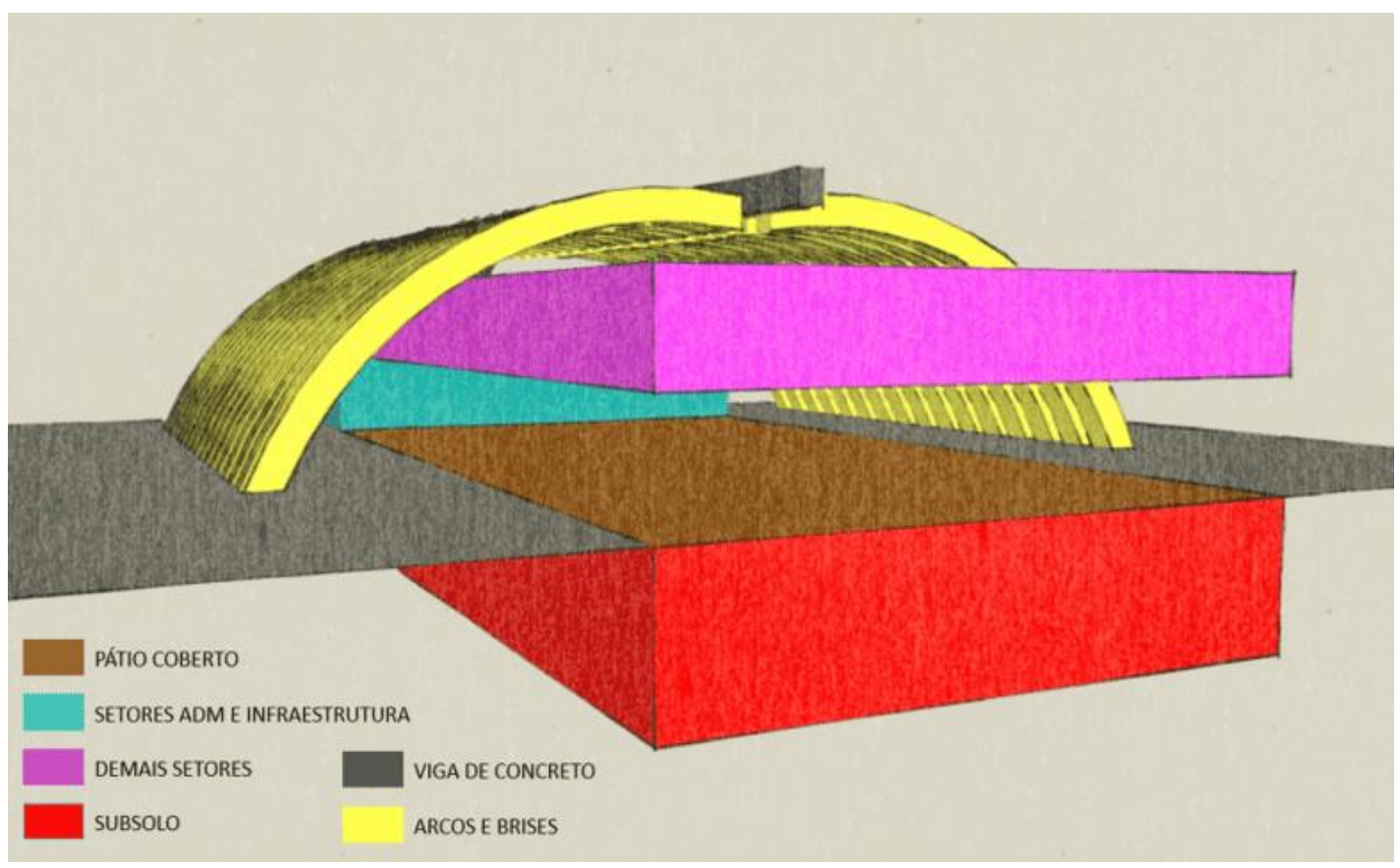

Fonte: Elaborado pela autora, 2019 
Os setores da edificação estão dispostos de maneira funcional, não havendo acessos interligados entre fluxos de funcionários e visitantes.

Os estudos de implantação do projeto buscaram priorizar, conforto ambiental por meio de uma ampla área permeável, recomposição de vegetação do cerrado, pé direito amplo, brises verticais automatizados e, o uso do vidro duplo termo-acústico.

Figura 23: Implantação.

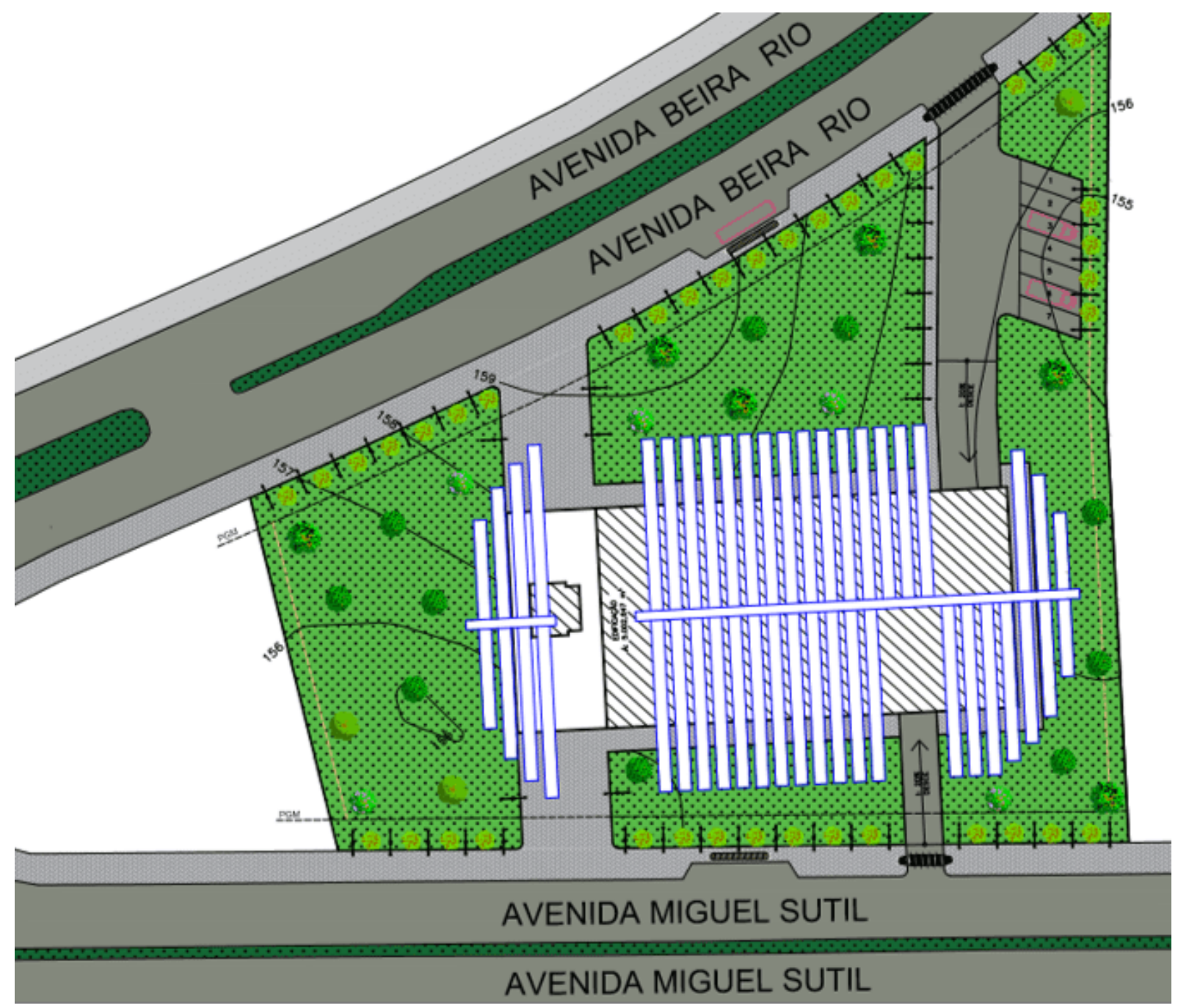

Fonte: Elaborado pela autora, 2019.

A figura 23 mostra a área destinada à construção do museu e, a localização da estrutura arquitetônica, juntamente com o estudo das diferentes espécies de árvores tipicamente do cerrado. 


\section{TÉCNICAS E MATERIAIS CONSTRUTIVOS}

Devido ao clima de Cuiabá, foram tomadas medidas significativas para a incorporação de materiais e técnicas ao projeto.

A estrutura da edificação é em peças pré-moldadas em concreto protendido de alta resistência que, além de possuir as mesmas características do concreto armado, contém cabos de aço tracionados e ancorados no concreto.

Figura 24: Diferenças entre o Concreto Armado e o Concreto Protendido.

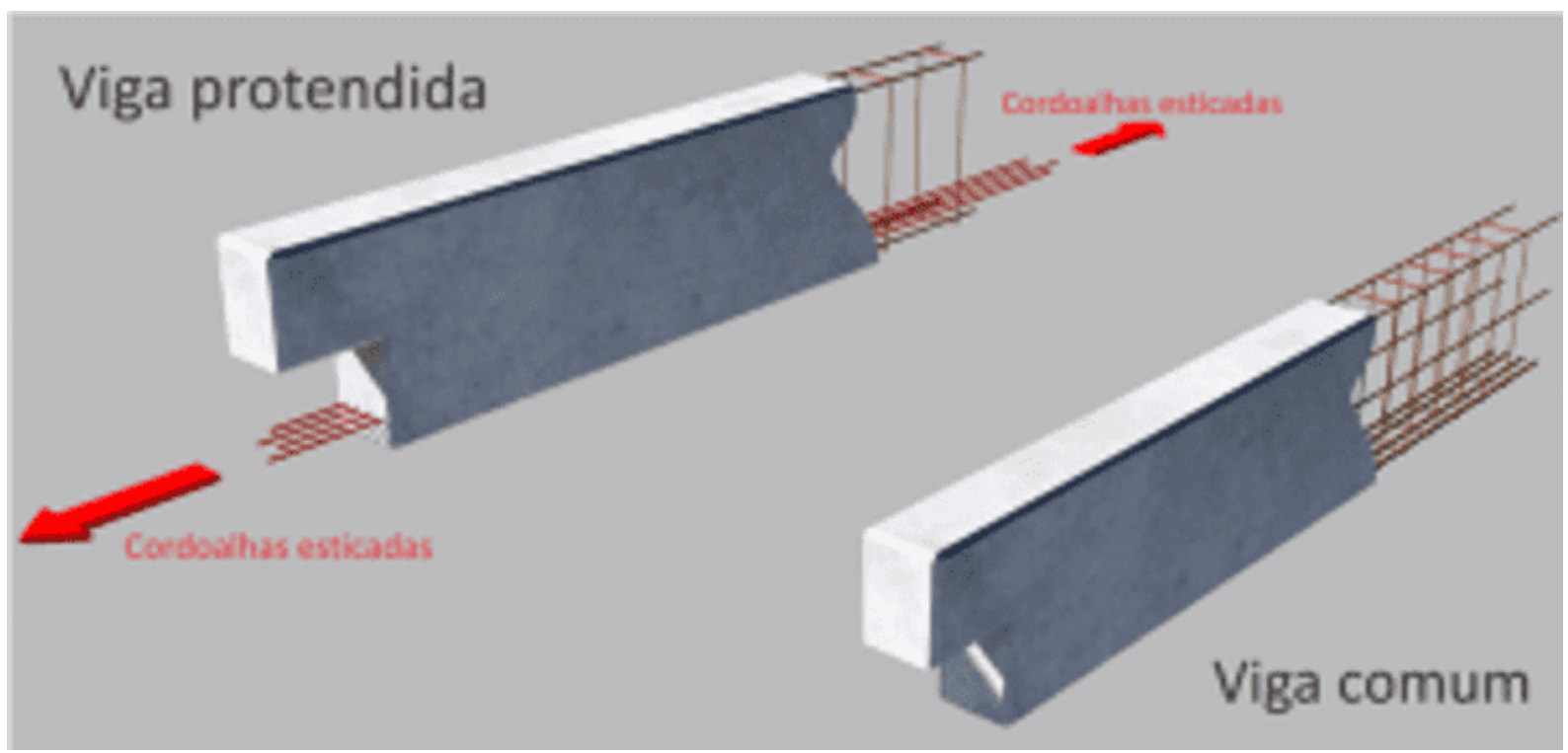

Fonte: Blog Maxi Educa. Acesso em 07 de Maio de 2019.

A estrutura metálica está presente nos arcos da edificação. $O$ aço possui uma construção mais limpa, pode ser reciclado e permite grandes vão livres. A espinha dorsal, seguido dos "espinhos" foi projetada em estrutura metálica para acomodar os brises presentes no projeto. Os brises se movimentam de forma vertical ao longo do arco de estrutura metálica, possuem a dimensão de $2,00 \times 2,00 \mathrm{~m}$ e são automatizados.

A sapata feita em concreto armado, é a isolada, um dos tipos de fundação mais simples e comum na construção civil. "As sapatas de fundação, são dimensionadas 


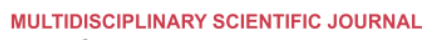

para que as tensões de tração que atuam sobre a fundação, sejam resistidas pela armadura e não pelo concreto" Pereira (2018).

Figura 25: Sapata Isolada.

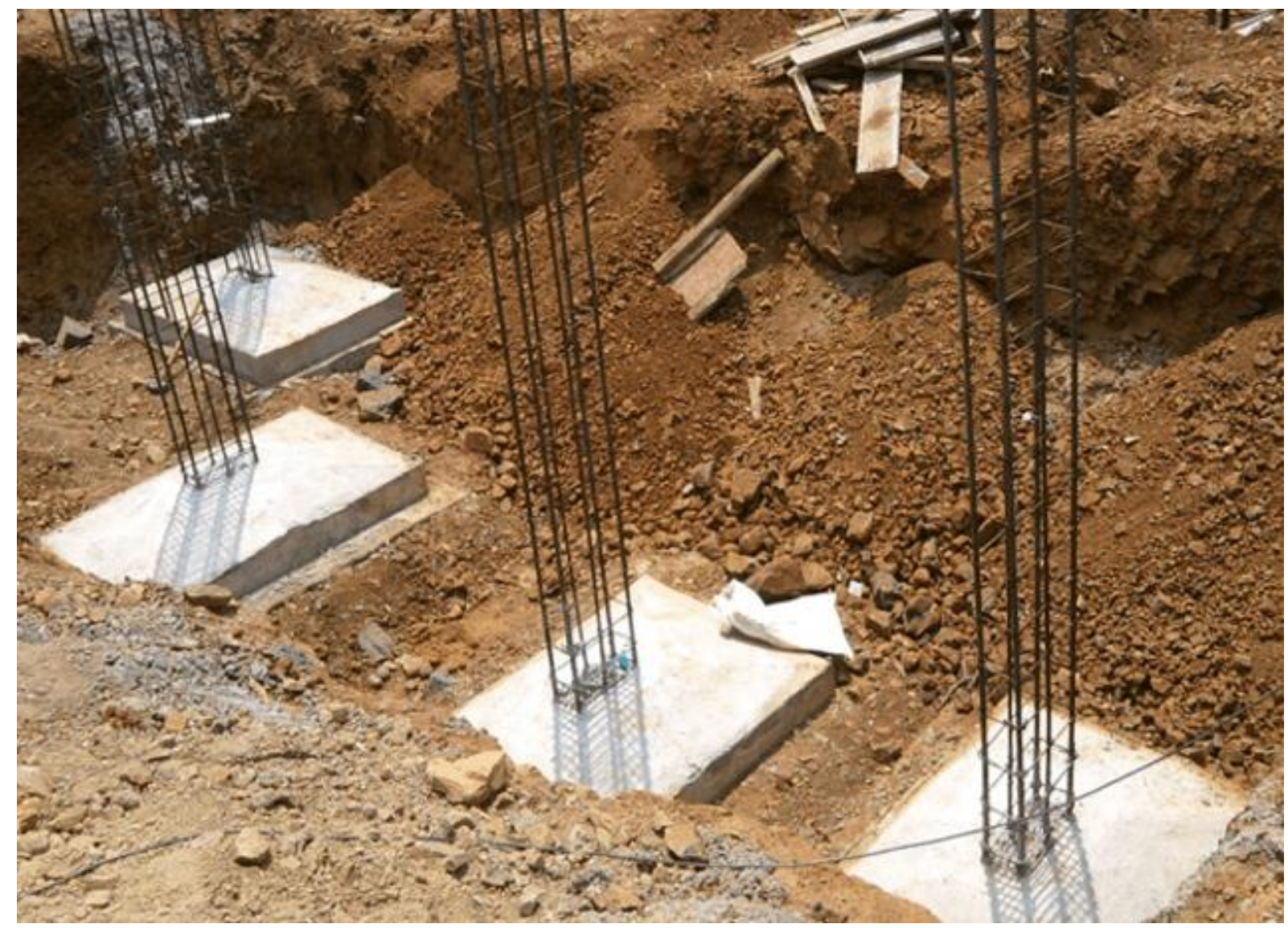

Fonte: Escola Engenharia. Acesso em 07 de Maio de 2019.

As vantagens dessa fundação são seu baixo custo, rapidez de execução e a capacidade de construção sem ferramentas ou equipamentos especiais.

Os cabos de aço foram incorporados ao projeto, pela sua desenvoltura em diferentes tipos de sustentação, neste caso, o cabo deverá sustentar a viga em balanço de concreto protendido. 
Figura 26: Cabo de Aço.

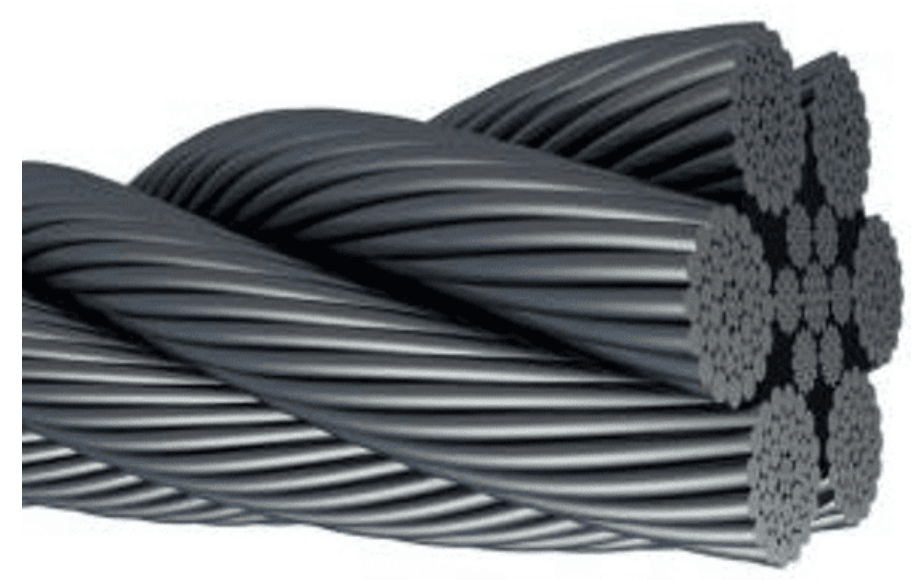

Fonte: Supreme Lubrificantes. Acesso em 07 de Maio de 2019.

Foi inserido no projeto, o Vidro Duplo Termo-acústico, em toda a envoltura do $1^{\circ}$ pavimento e nas demais esquadrias.

Figura 27: Vidro Duplo Termo-acústico.

\section{VIDRO DUPLO TERMO-ACÚSTICO}

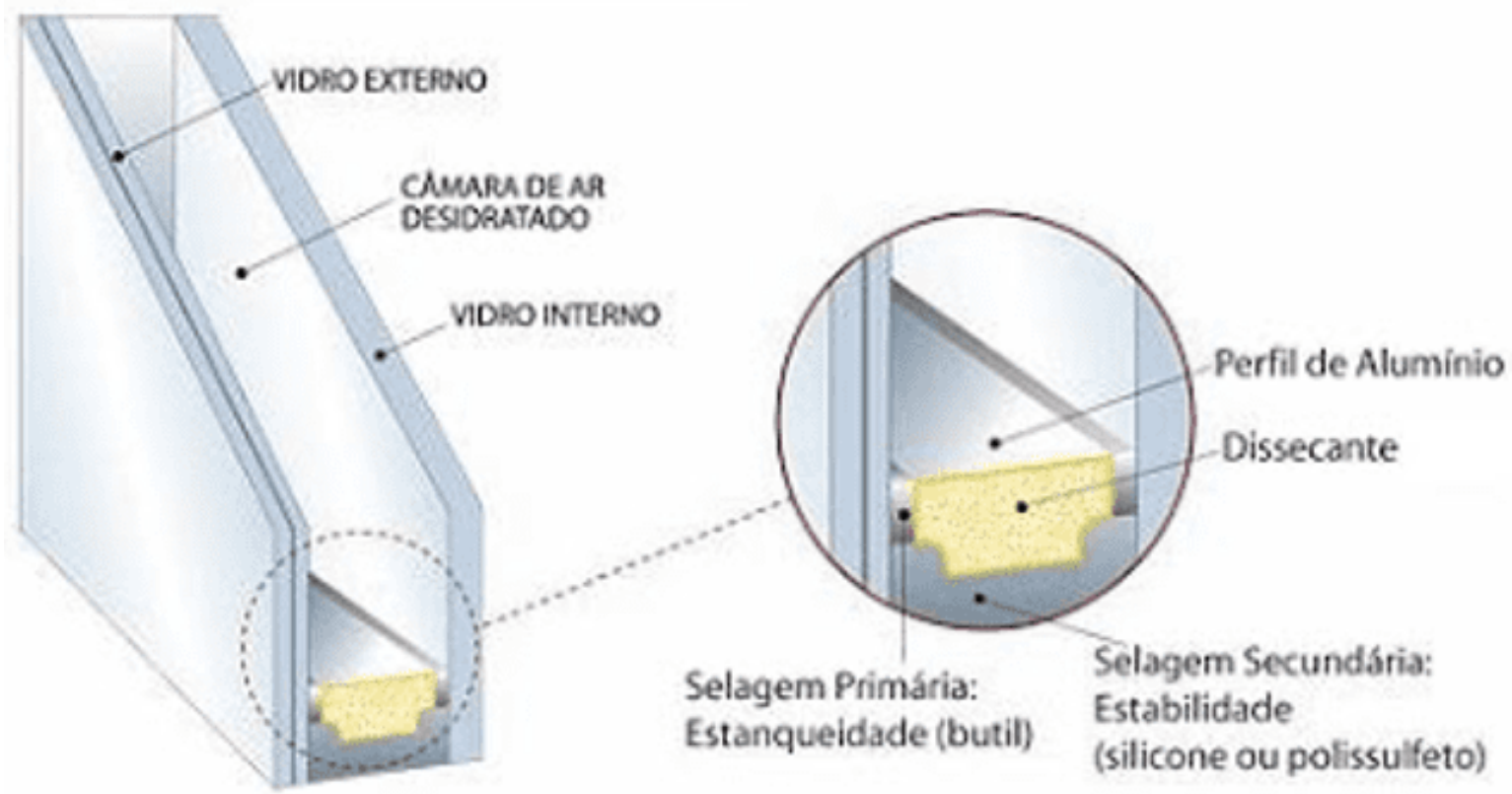

Fonte: Clique Arquitetura. Acesso em 07 de Maio de 2019. 
Os vidros termo-acústicos são indicados para a redução de ruídos e proporciona também um conforto térmico considerável. Sua composição é de 2 lâminas de vidro, paralelas e com espaçamento de ar desidratado entre elas.

Para pavimentação foi utilizado o piso intertravado de concreto retangular, de fácil manutenção, sem perda de material e com a grande vantagem de reduzir impactos ambientais.

Figura 28: Piso intertravado de concreto retangular, a tipologia que será usada na proposta do projeto.

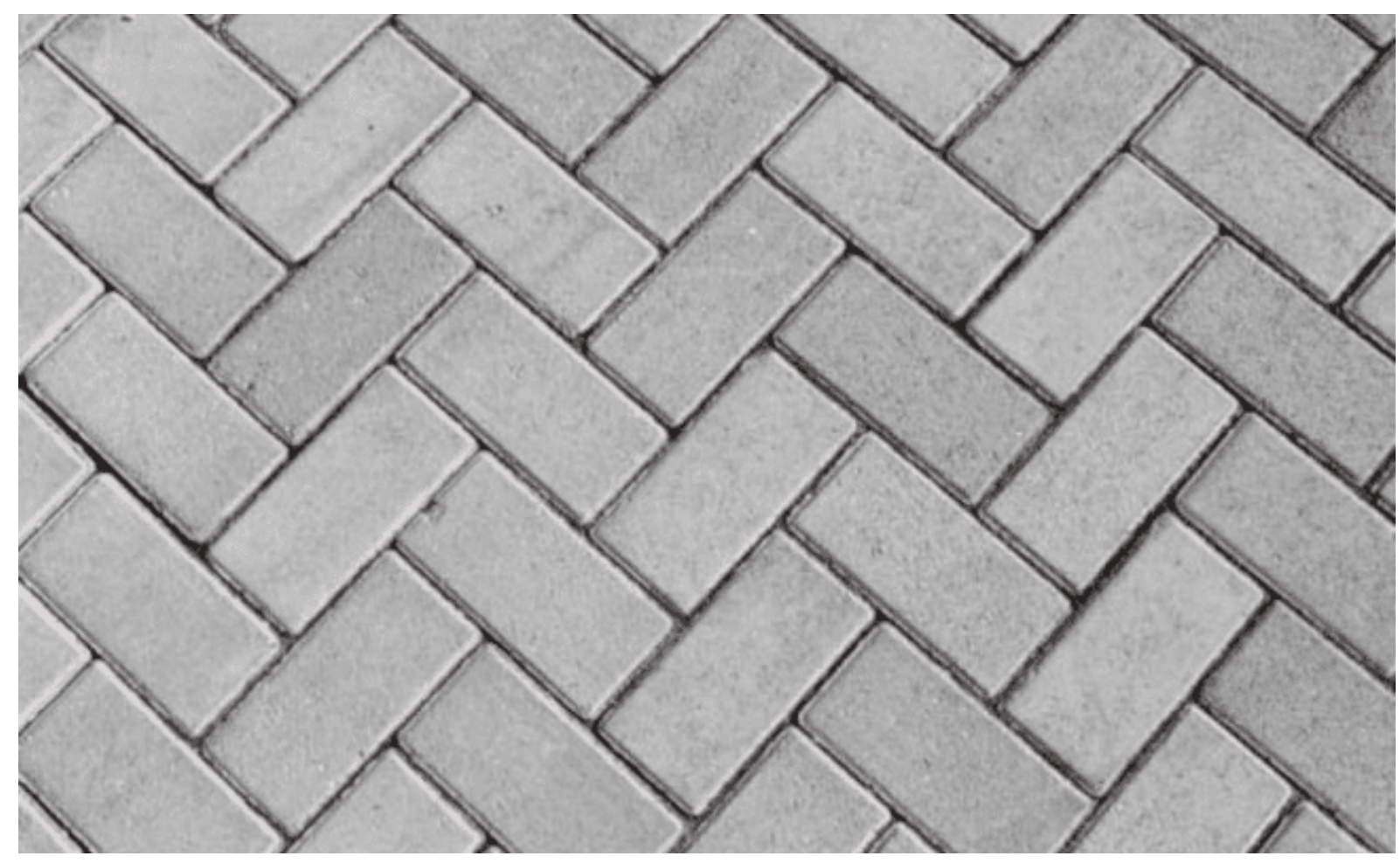

Fonte: Escola Engenharia. Acesso em 29 de Maio de 2019.

\section{RESULTADOS}

Foram observadas diferentes de estratégias arquitetônicas que permitiram a construção do projeto Museu de Arte de Cuiabá. A integração na estrutura arquitetônica das imagens iconográficas representativas, arquitetura indígena e escama de peixe foram inseridas de forma funcional e estética, num projeto moderno 
que valoriza e integra passado e futuro. Abaixo podem ser vistas algumas figuras antecipando visualmente, as estruturas internas e externas e suas relações com a história e culturas locais.

Figura 29: Recepção do Museu.

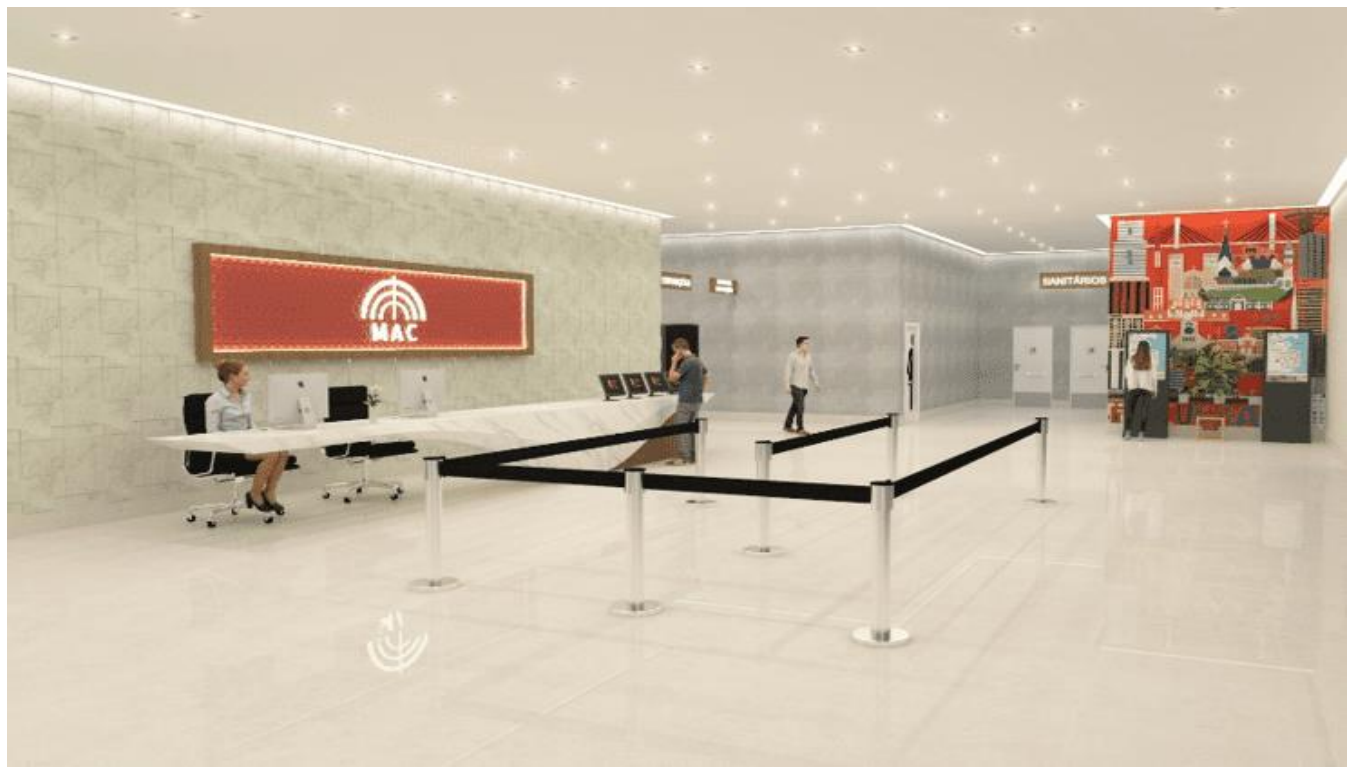

Fonte: Elaborado pela autora, 2019.

Figura 30: Sala de Exposição Permanente.

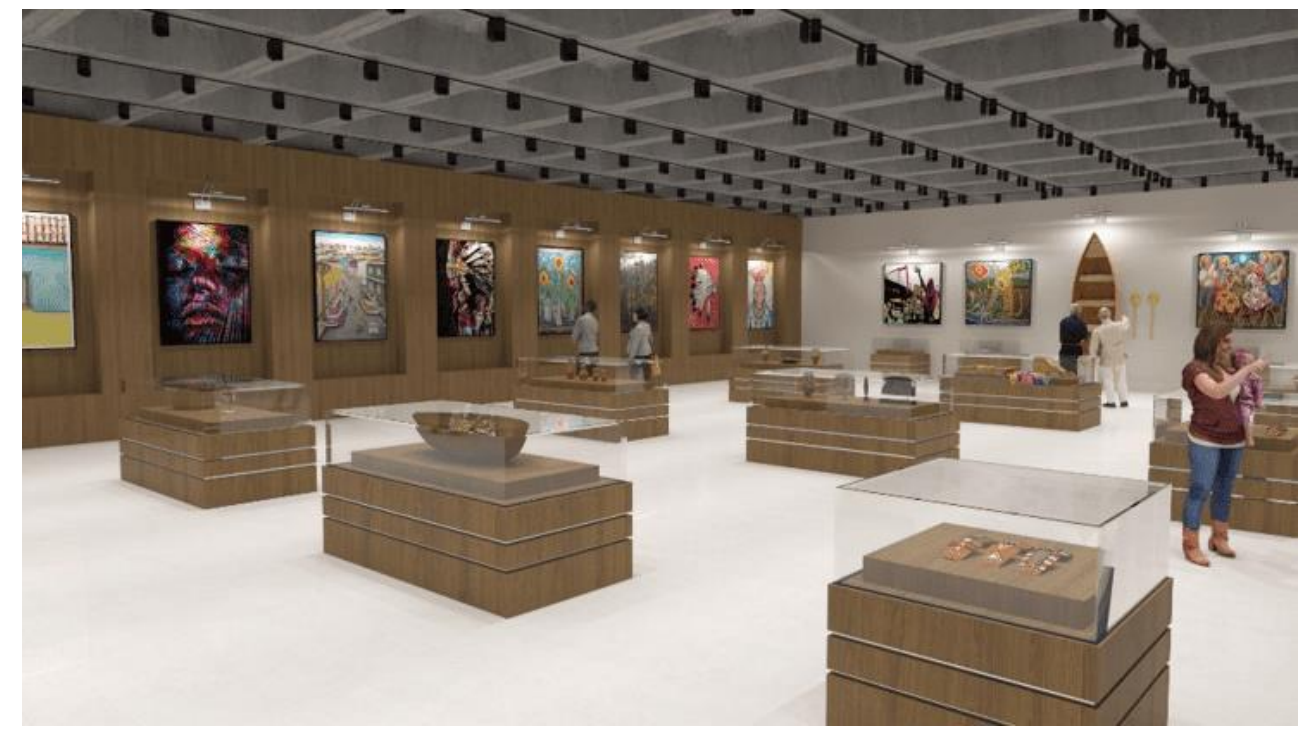

Fonte: Elaborado pela autora, 2019. 
Figura 31: Café Externo.

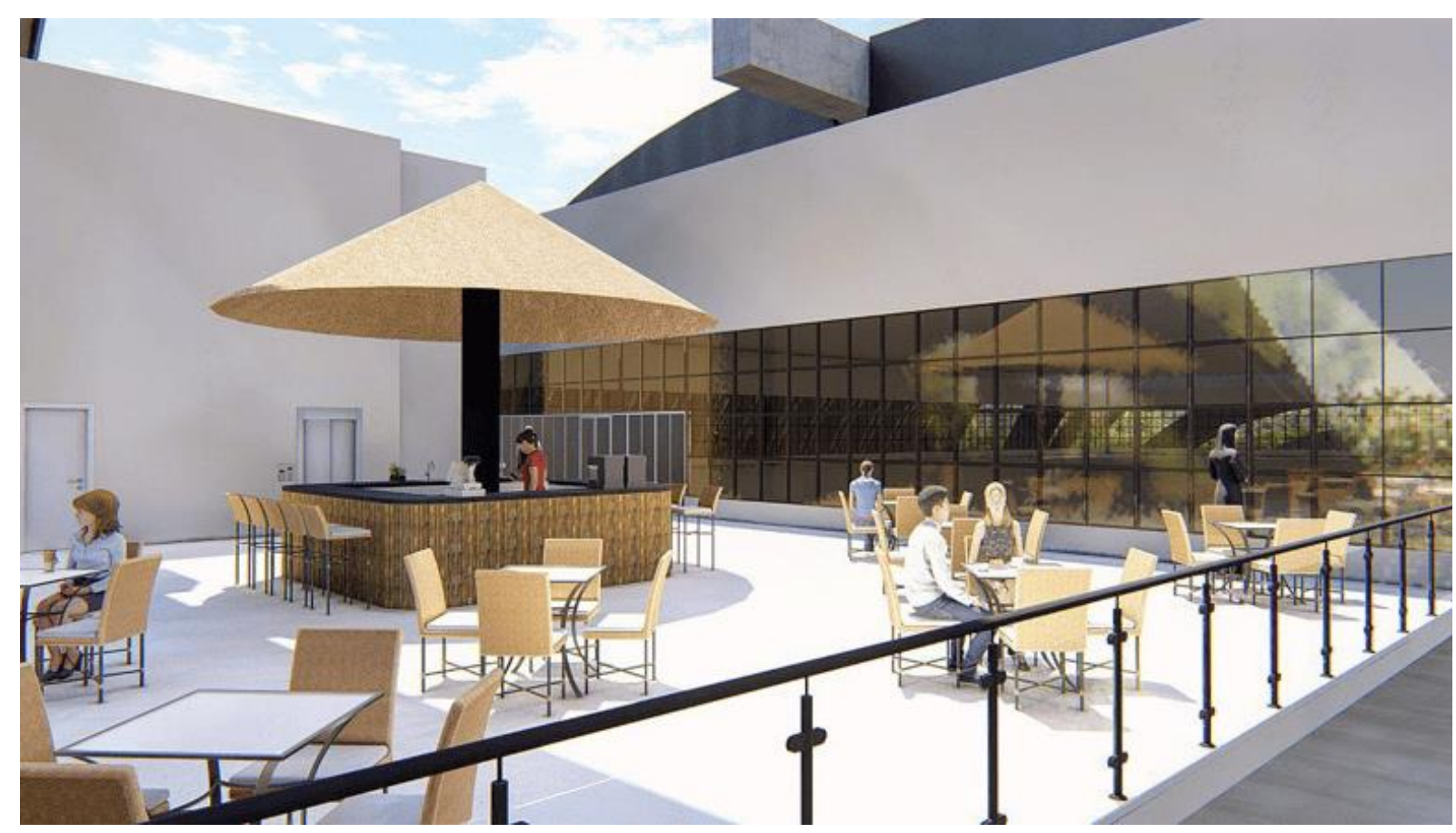

Fonte: Elaborado pela autora, 2019.

Figura 32: Exposição Regional Externa.

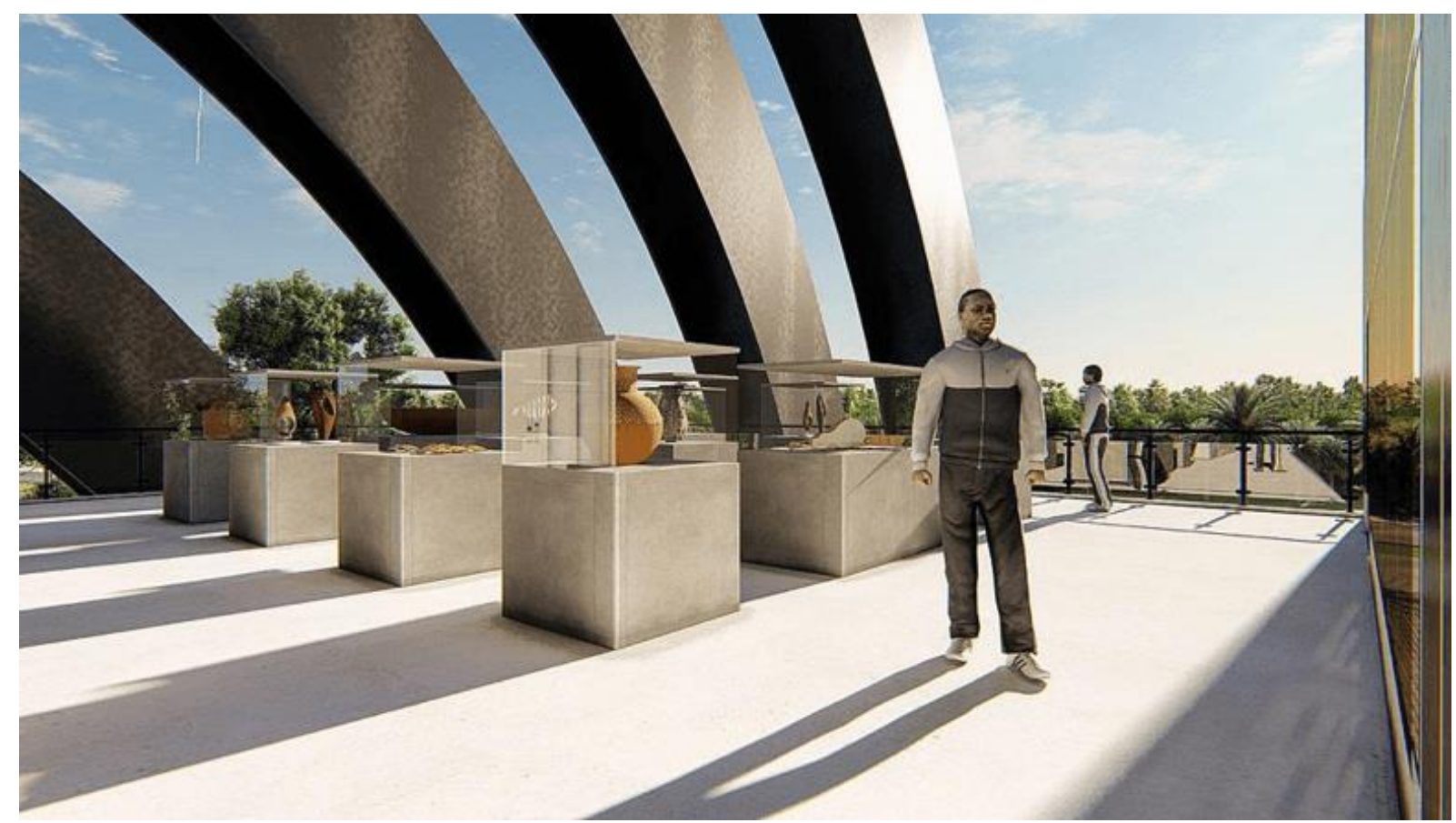

Fonte: Elaborado pela autora, 2019. 


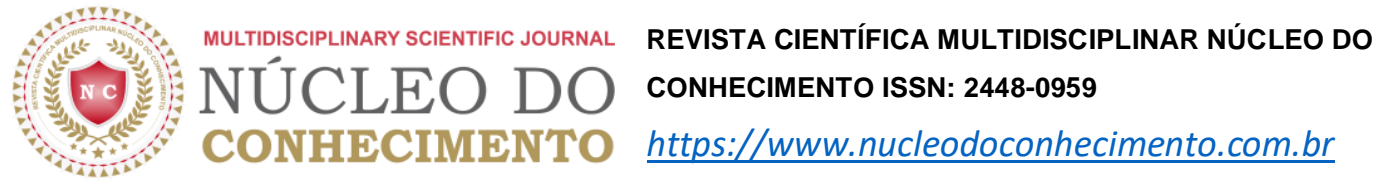

Figura 33: Perspectiva Externa.

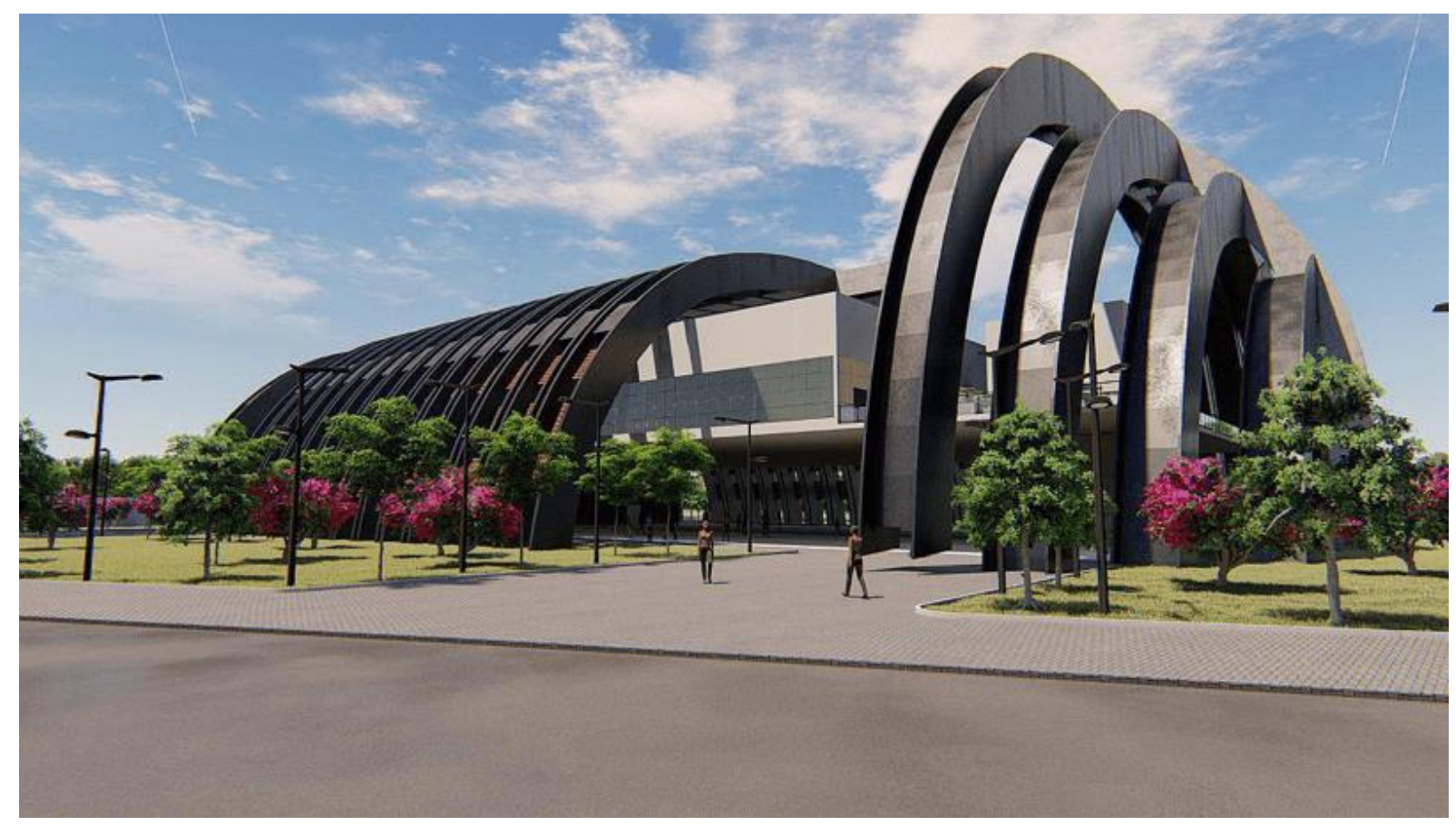

Fonte: Elaborado pela autora, 2019.

Figura 34: Perspectiva Externa.

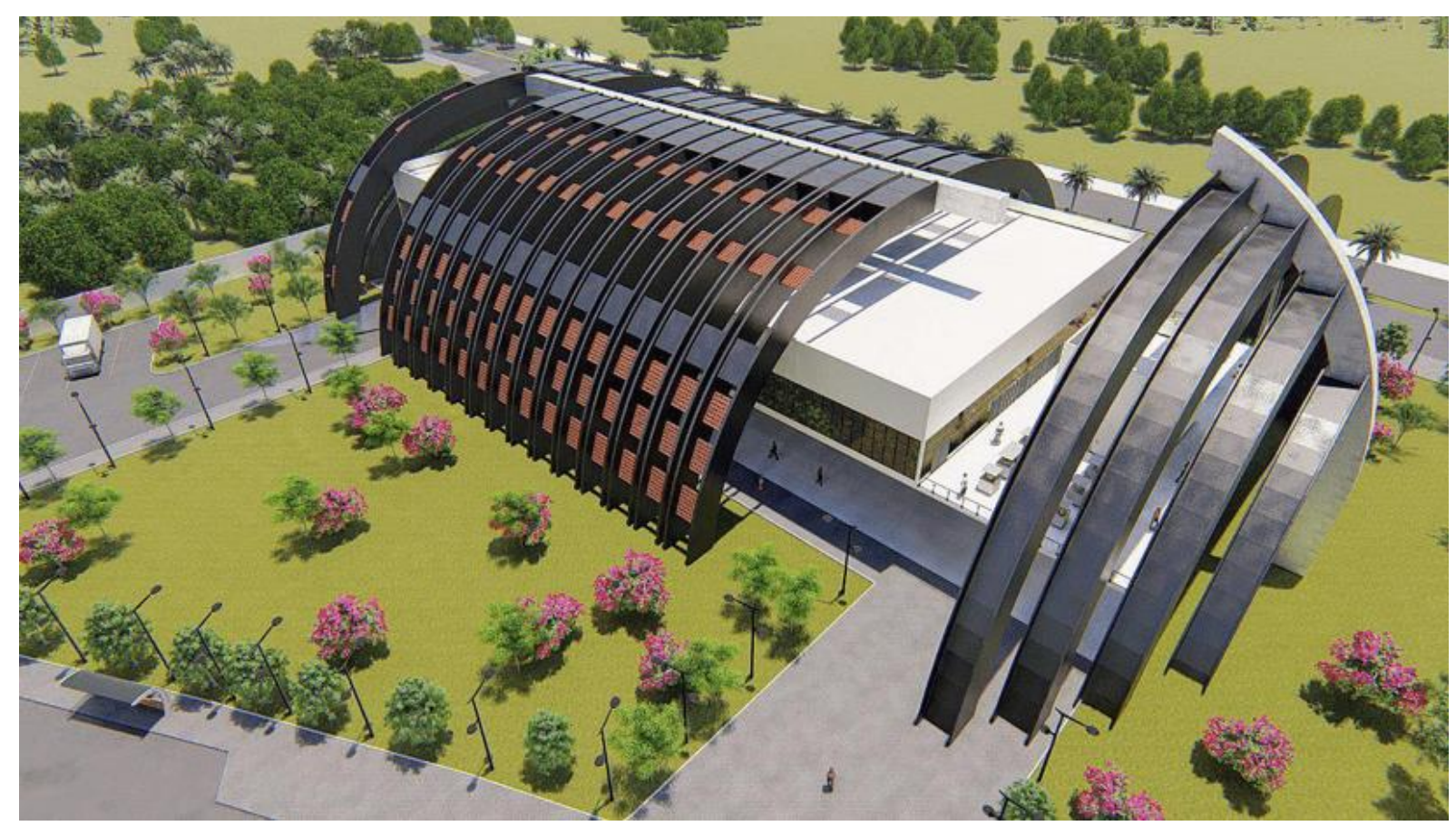

Fonte: Elaborado pela autora, 2019.

Disponível em: https://www.nucleodoconhecimento.com.br/arquitetura/proposta-projetual 


\section{MULTIDISCIPLINARY SCIENTIFIC JOURNAL

Figura 35: Perspectiva Externa.

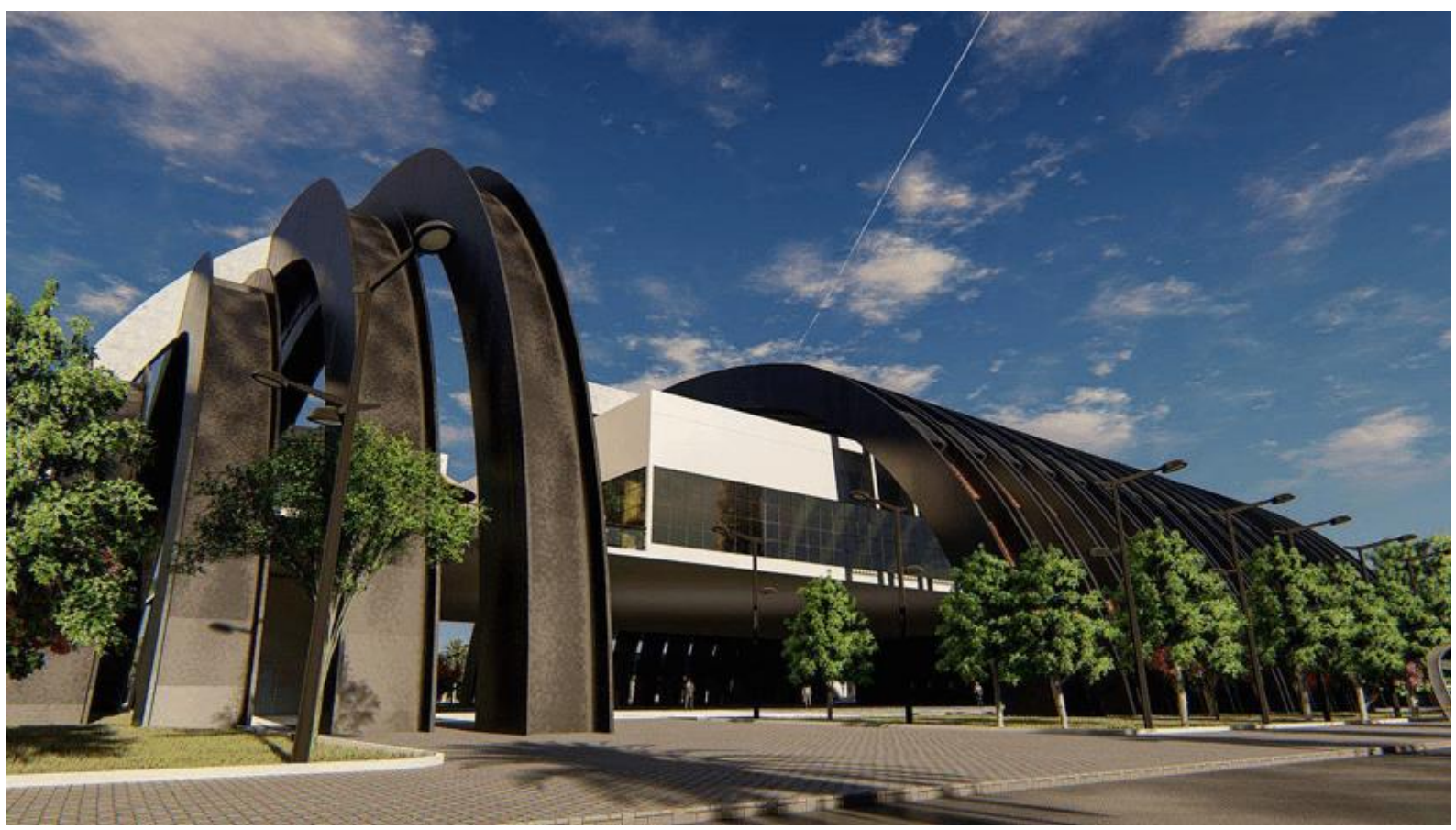

Fonte: Elaborado pela autora, 2019.

Figura 36: Logo do Museu.

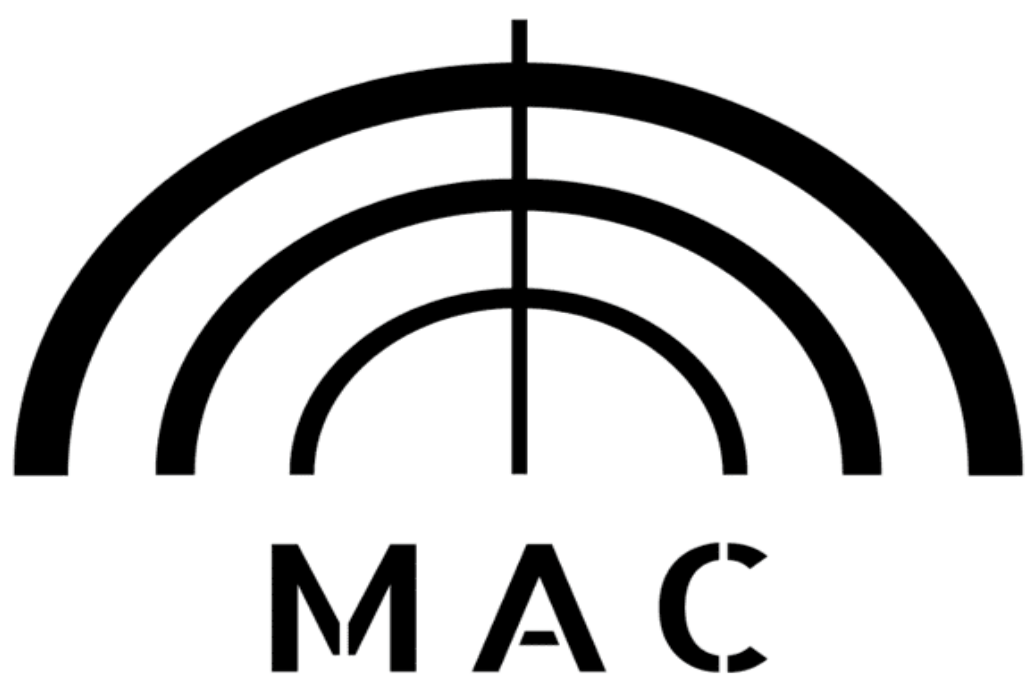

Fonte: Elaborado pela autora, 2019.

O projeto e sua volumetria foram utilizados como base para a criação e formação da Logo do Museu. Intitulado MAC - Museu de Arte de Cuiabá. 


\section{CONCLUSÃO}

A proposta de um Museu de Arte para Cuiabá tem como principal objetivo incentivar e destacar a cultura local, bem como apresentar obras de outros artistas brasileiros além de internacionais. $O$ projeto abre portas para o conhecimento, entretenimento, diversão e lazer com as áreas expositivas e de educação, sendo um local de fomentação e formação de conhecimento.

A volumetria irreverente da edificação está diretamente associada com Cuiabá, Porto e Arte; onde se tem a espinha dorsal e demais espinhos em uma espécie de "Casca" envolta da edificação, representando o peixe que sempre foi presente na cultura local, contrastando com a arquitetura moderna com o uso de concreto protendido e vidros. A edificação, de arquitetura inovadora, tem por objetivo atrair a curiosidade e a imaginação do público, além de proporcionar cultura e lazer.

\section{REFERÊNCIAS}

ALMANDRADE. [Antonio Luiz Morais de Andrade]. 0 museu e sua função cultural. $\begin{array}{llll}\text { Cultura e } & 2008 . & \text { Disponível }\end{array}$ <http://www.culturaemercado.com.br/site/pontos-de-vista/o-museu-e-sua-funcaocultural/>. Acesso em: 01 de Out. 2018.

ANICO, Marta. A pós-modernização da cultura: patrimônio e museus na contemporaneidade. Horizontes Antropológicos, Porto Alegre, ano 11, n. 23, p. 71 86, jan/jun 2005. Disponível em: <http://www.scielo.br/pdf/ha/v11n23/a05v1123.pdf>. Acesso em: 18 de Set. 2018.

ARGAN, G.C. História da Arte como história da cidade. Tradução de Pier Luigi Cabra. 6ํe., São Paulo: Martins Fontes, 1989.

ASSOCIAÇÃO BRASILEIRA DE NORMAS TÉCNICAS. NBR 15220-3: Desempenho térmico de edificações. Parte 3: Zoneamento bioclimático brasileiro e diretrizes construtivas para habitações unifamiliares de interesse social. Rio de janeiro. 2003. 
AWA COMERCIAL. Concreto protendido ou armado? Conheça as diferentes aplicações. 2016. Disponível em: < http://awacomercial.com.br/blog/concretoprotendido-ou-armado-conheca-as-diferentes-aplicacoes/ >. Acesso em: 07 de Maio de 2019.

CHAGAS, Mario de Souza. Um novo (velho) conceito de museu. Cad. Est. Soc. Recife, v.1 n.2, p.183 - 192, jul/dez, 1985.

CONSELHO INTERNACIONAL DE MUSEUS (ICOM). Código de ética para museus. Tradução: Comitê Brasileiro do ICOM - Gestão 2003 - 2006. São Paulo, 2006.

GEHL, Jan. Cidades para Pessoas. Tradução de Anita Di Marco. 2ํo ed., São Paulo: Perspectiva, 2013.

HOLANDA, Marina. Clássicos da Arquitetura: MASP / Lina Bo Bardi. 2012. Disponível em: < https://www.archdaily.com.br/br/01-59480/classicos-da-arquiteturamasp-lina-bo-bardi >. Acesso em: 22 de Março de 2019.

IBRAM, Instituto Brasileiro de Museus. Museus em Números. Vol. 1, Brasília, 2011.

KANTOR, Lana. O que é telha termoacústica (sanduíche)? Tire todas as suas dúvidas. Disponível em: < https://www.hometeka.com.br/aprenda/o-que-e-telhatermoacustica-sanduiche/ >. Acesso em: 22 de Março de 2019.

LAMBERTS, R.; DUTRA, L.; PEREIRA, F.O.R. Eficiência energética na Arquitetura. 3.ed. Rio de Janeiro, 2014.

O LIVRE. Maioria dos museus de Cuiabá não funciona; alguns, há mais de 1 ano. 2018. Disponível em: < https://olivre.com.br/maioria-dos-museus-de-cuiaba-naofunciona-alguns-ha-mais-de-1-ano/ >. Acesso em: 29 de Out. 2018.

INEP. Centro de Previsão de Tempo e Estudos Climáticos. 2019. Disponível em: < https://www.cptec.inpe.br/previsao-tempo/mt/cuiaba >. Acesso em: 22 de Março de 2019. 
PEREIRA, Caio. Estrutura Metálica: Processo executivo, vantagens e desvantagens. 2019. Disponível em: < https://www.escolaengenharia.com.br/estrutura-metalica/ >. Acesso em: 07 de Maio de 2019.

PEREIRA. Caio. Sapatas de fundação. 2018. Disponível em: < https://www.escolaengenharia.com.br/sapatas-de-fundacao/ > Acesso em: 07 de Maio de 2019.

PEREIRA. Caio. Piso Intertravado: 0 que é, principais tipos, vantagens e desvantagens. 2019. Disponível em: < https://www.escolaengenharia.com.br/pisointertravado/ >. Acesso em: 29 de Maio de 2019.

SOUZA, Eduardo. Museu The Broad / Diller Scofidio + Renfro. 2012. Disponível em: < https://www.archdaily.com.br/br/773021/museu-the-broad-diller-scofidio-plusrenfro >. Acesso em: 22 de Março de 2019.

SUPREME LUBRIFICANTES. Cabos de Aço. 2015. Disponível em: < http://www.supremelub.com.br/noticias/15/cabos-de-aco >. Acesso em 07 de Maio de 2019.

VOITILLE, Nadine. Vidro isolante termo-acústico. 2012. Disponível em: < https://www.cliquearquitetura.com.br/artigo/vidro-isolante-termo-acustico.html >. Acesso em 07 de Maio de 2019.

Enviado: Agosto, 2019.

Aprovado: Janeiro, 2020. 